\title{
Hydrographical variability on the French continental shelf in the Bay of Biscay, during the 1990s
}

\author{
I. Puillat ${ }^{\mathrm{a}^{*}}$, P. Lazure ${ }^{\mathrm{a}}$, A. M. Jégou ${ }^{\mathrm{a}}$, L. Lampert ${ }^{\mathrm{b} 1}$ and P. I. Miller \\ IFREMER/DEL/AO, BP 70, 29280, Plouzané, France \\ ${ }^{\mathrm{b}}$ EPSHOM, BP 426, 29275, Brest cédex, France \\ 'Plymouth Marine Laboratory (PML), Prospect Place, Plymouth PL1 3DH, UK \\ *: Corresponding author : Tel.: +33-2-98-22-43-48; fax: +33-2-98-22-45-55 gridpuillat@yahoo.fr
}

\begin{abstract}
:
A synthesis of 9 years of hydrographic measurements, acquired during approximately 25 cruises (1992-2000) on the French continental shelf of the Bay of Biscay, is presented. The main focus is upon salinity distribution, as it is little known in this area. The whole of the data set covers 11 months of the year, with some sampling fields repeated several times a year, for multiple years. This timeseries allows temperature and salinity distributions to be studied together with their seasonal, interannual and mesoscale variability.
\end{abstract}

The seasonal trend in temperature can be described in three stages, which are in agreement with past studies. Thermal stratification occurs between May and mid-September in a layer not, vert, similar50 $\mathrm{m}$ in thickness, whereas the water column remains homogenous from January to the beginning of April. The mid-September-December period corresponds to the progressive destruction of the thermocline.

In contrast, the salinity distribution displays two main seasonal patterns. From March to June, the haline stratification is strong; this is in response to high river runoff and relatively low vertical mixing. In autumn, stratification decreases because of low river discharge and wind-induced vertical mixing. Surface salinity increases by up to 1 psu inshore of the $100-\mathrm{m}$ isobath, from spring to end of summer. The salinity gradient runs cross-shore in spring and along-shore in summer: this is due to the mean wind direction during the previous 6 months (SW from September to March, NW from March to September). Nevertheless, this seasonal signal could be biased by the high inter-annual variability. Indeed, the monthly extent of low surface salinity $(S<35)$ varied between years, this is driven by river runoff over the previous 3-6 months and short-term wind events (not, vert, similar10 days), particularly when they are upwelling-favourable. Forcing at these time-scales are responsible also for mesoscale structures, such as lower salinity lenses and wind-induced coastal upwelling off Southern Brittany. In the deeper layers the inter-annual variability of a denser water structure named (the "Cold Pool") is also investigated.

Consequently, the inter-annual, seasonal and mesoscale variability in salinity patterns are caused by (i) river runoff from the Loire and Gironde, that reduces surface salinity locally; and (ii) the wind that influences the location of low salinity water masses. Mesoscale structures and the observed links between inter-annual and seasonal variability, raise problems in relation to the interpretation of in situ data, making it impossible to establish the actual mean distribution. There is a pressing need within the Bay of Biscay, for sampling at higher spatial and temporal resolution.

Keywords: Hydrography; Salinity; Seasonal variability; River plumes; Cold pool; Upwelling 


\section{Introduction}

The Bay of Biscay is located at mid-latitudes in the north-eastern Atlantic, off western Europe. In this paper, we will focus on the French continental shelf area (Fig. 1). The oceanic part of the bay $(z>2000 \mathrm{~m})$ has been relatively well studied in numerous papers (e.g. Pingree and Le Cann, 1989; Le Cann and Pingree, 1995; Van Haken, 2001). In this area, the general circulation is anticyclonic and weak, with geostrophic currents of $1-2 \mathrm{~cm} \cdot \mathrm{s}^{-1}$ in the surface layer. Along the continental slope, sub-tidal residual currents are stronger: $5-10 \mathrm{~cm} \cdot \mathrm{s}^{-1}$ at $500 \mathrm{~m}$, measured by currentmeters and drifting buoys, they are mainly oriented poleward (Pingree and Le Cann, 1990; Le Cann et al., 1997). However, these currents have vertical and along- and across-slope components, vary seasonally, and can be unstable and generate mesoscale eddies, known as SWODDIES (Slope Water Oceanic eDDIES, Pingree and Le Cann, 1992). In winter, a poleward surface flow develops along the western Iberian Peninsula and usually enters the Bay of Biscay around Christmas, so is called the "Navidad" (Frouin et al., 1990; Pingree and Le Cann, 1992). This slope current is characterised by the warmest temperature of the year at $200 \mathrm{~m}$, in January and February (Pingree, 1994).

In contrast to the oceanic domain, observations on the shelf are scarce and long-term current records are lacking; these can be reviewed in Le Cann (1982) and Koutsikopoulos and Le Cann, (1996). General circulation is weak, with a residual sub-tidal current of about 2-5 $\mathrm{cm} . \mathrm{s}^{-1}$ which is strongly variable in speed and direction. Circulation over the shelf is mainly driven by tides, winds and density gradients. On the French shelf, tidal currents are better studied than wind- and density-induced currents (Pingree et al., 1982; Le Cann, 1990). Wind effects have only been studied over the Celtic and the Armorican shelves from model simulations, together with a few in-situ measurements (Pingree and Le Cann, 1989). These results do not explain the variability in coastal areas nor at a mesoscale. From some model 
simulations (Lazure and Jégou, 1998), it can be inferred that the wind would influence the plume orientation; hence, the baroclinic flow around it. However, such simulations have not been compared with in-situ measurements because hydrographical data are lacking, particularly salinity. The in-situ salinity distribution, its seasonal and mesoscale variability, as well as the wind's influence, have not been specifically described.

This article sets out to fill those gaps, insofar as is possible on the basis of previously unpublished hydrographical in-situ data, acquired between 1992 and 2000 over the French continental shelf. The main focus is on salinity distributions for several reasons. The first is that salinity is generally a good tracer for water masses and, as such, provides indications for the study of dynamics and freshwater influence. Secondly, temperature has been the object of more investigation in the literature. Density distribution is not described here, since it is a function of the latter two parameters; likewise because it is our intention to investigate hydrographic features (a further paper will consider dynamic features). Finally, studying hydrographic features in this coastal area is also relevant to fisheries issues. For instance, the distribution of spawning activity can be influenced by rivers plumes, as shown during surveys where high concentrations of anchovy eggs were observed in isolated lower salinity lenses, far away from the coast (e.g. Motos et al., 1996; Sanchez and Gil, 2000).

Dynamic and hydrographic observations, already published, together with those elements of the dynamics affecting hydrographic variability are reviewed in the next section. After presenting the data and the methods used, our results focus on monthly and seasonal trends in the temperature and salinity distributions, on the inter-annual variability of the surface salinity distribution and on mesoscale structures. Conclusions are drawn on the links between inter-annual and seasonal variability and the mesoscale phenomena. 


\section{Dynamics and hydrography on the Bay of Biscay shelf: background}

\subsection{Dynamics}

The few available measurements exibit a residual sub-tidal current of 2-5 $\mathrm{cm} . \mathrm{s}^{-1}$, flowing poleward over the Armorican shelf (Le Cann, 1988; see Pingree and Le Cann, 1989 for a review of existing data). However, stronger intermittent surface sub-tidal currents have been recorded with current meters $\left(\sim 22 \mathrm{~cm} \cdot \mathrm{s}^{-1}\right.$ : Pingree and Le Cann, 1989) and drifting buoys (average $\sim 20-30 \mathrm{~cm} . \mathrm{s}^{-1}$ on a 9-day period: Castaing, 1984). This variability is due mainly to tidal currents, wind-induced currents and density gradient currents.

Tidal currents are due mainly to the semi-diurnal component (M2). In the southern part of the bay (south of $45^{\circ} \mathrm{N}$ ), the tidal currents are relatively weak, at less than $15 \mathrm{~cm} . \mathrm{s}^{-1}$ (Le Cann, 1990) and the water mass circulation is governed principally by wind-induced and density currents. Northwards, near the Vendée coast and southern Brittany coast, between the Glenan and Belle Ile islands, currents do not exceed $10 \mathrm{~cm} \cdot \mathrm{s}^{-1}$ (Pingree et al., 1982; Le Cann, 1990). Over the Armorican shelf, the tidal currents are stronger $\left(\sim 30 \mathrm{~cm} . \mathrm{s}^{-1}\right)$, with maxima exceeding $50 \mathrm{~cm} \cdot \mathrm{s}^{-1}$ in the vicinity of some islands.

The strength and the direction of the wind-induced currents are highly variable, over the shelf. By analysing in-situ data and model simulations on the Armorican shelf, Pingree and Le Cann (1989) have shown that northwesterly (NW) winds create the largest current response. On the Celtic and Armorican shelf $\left(43-53^{\circ} \mathrm{N}\right)$, NW winds should induce south-south-eastward currents over the French shelf. Over the Armorican and the northern part of the Aquitaine shelves, currents generated are typically $\sim 10 \mathrm{~cm} \cdot \mathrm{s}^{-1}$ and, locally, 20-30 cm.s. ${ }^{-1}$. The SW wind reverses the circulation towards the northwest, as is also the case for southerly winds. The main characteristic is the relatively rapid response of shelf waters to permanent wind stress 
(of less than 4 days). Farther to the south, wind-driven circulation is more complicated because of the narrow shelf topography, where circulation over the slope should affect the shelf. Jégou and Lazure (1995) have shown that vertical movements induced by upwellingfavourable winds are stronger when tidal currents are weak. The Landes and Vendée coast and, to a lesser degree the southern part of Brittany are, therefore, most susceptible to upwelling due to generally low tidal currents. On either side of the Loire estuary, upwellings are not generated by the same wind directions because of the coastline orientation (Lazure and Jégou, 1998). In agreement with Ekman theory, northwesterly to northerly winds induce upwelling to the south of the Loire, because the coastline is oriented N-S. Westerly to northwesterly winds generate upwelling to the north of the Loire, as the coastline is oriented NW-SE.

Density currents are observed in the vicinity of estuaries, as rivers discharge freshwater into the surface layers. The Loire and the Gironde are the two main rivers on France's Atlantic coast, each with annual mean freshwater outflows of about $900 \mathrm{~m}^{3} . \mathrm{s}^{-1}$. Both have a minimum (in summer) of about $200 \mathrm{~m}^{3} \cdot \mathrm{s}^{-1}$ and a peak runoff (in winter or spring) exceeding $3000 \mathrm{~m}^{3} \cdot \mathrm{s}^{-1}$, which can induce significant density currents of $\sim 10 \mathrm{~cm} \cdot \mathrm{s}^{-1}$ in model simulations (Lazure and Jégou, 1998). These density currents generally flow northwards at the surface, because of the Earth's rotation, however, are affected frequently by the wind-induced circulation, as shown by the plume trends taken from the model results of Lazure and Jégou (1998). Other rivers such as the Adour and Vilaine (annual mean outflow $\sim 300 \mathrm{~m}^{3} . \mathrm{s}^{-1}$ ) have less influence on the density currents. 


\subsection{Thermal variability}

Seasonal changes in thermal distribution in the Bay of Biscay were first described by Vincent and Kurc (1969) and Vincent (1973), then completed and reviewed by Le Cann (1982), Koutsikopoulos and Le Cann (1996) and Koutsikopoulos et al. (1998). The latter highlighted, particularly, sea surface temperature (SST) variability in the bay, whilst some mesoscale features were observed.

In winter, the water column is generally homogenous but a thermal inversion, with colder waters in the surface layer, can be observed; this is most distinct near the estuaries. This vertical inversion is linked primarily to the presence in the surface layer of some lesssaline and cold water masses, of continental origin. Minimum temperatures range from 8.0$9.5^{\circ} \mathrm{C}$ and the mean SST varies from $\sim 11-12^{\circ} \mathrm{C}$, over the French shelf. The main mesoscale hydrographic features are the river plumes.

In spring, the seasonal thermocline appears most markedly in the south, where tidal current mixing is low. The mean SST increases from $11-12^{\circ} \mathrm{C}$ to $15-17^{\circ} \mathrm{C}$, on the shelf. A cold water mass is isolated below warmer surface water. This cold pool (CP), called also the "Bourrelet froid" (Vincent and Kurc, 1969), is nearly homogenous $\left(<11-12^{\circ} \mathrm{C}\right)$. It elongates along the shelf break from southern Brittany, down to the latitude of the Gironde estuary, centred over the $100 \mathrm{~m}$-deep zone. Its location corresponds to the zone of weak tidal stirring, between areas of stronger vertical mixing along the Brittany coast and along the Armorican shelf break (Le Fevre, 1986). This structure is present throughout the year, except in winter when the water column is homogenous. It appears to be characterised by low inter-annual and seasonal fluctuations, with small variations in temperature (less than $1{ }^{\circ} \mathrm{C}$ from spring to autumn) (Vincent, 1973). 
In summer, strong vertical temperature gradients are observed. According to recorded temperature profiles off the Loire $\left(47^{\circ} \mathrm{N}-3^{\circ} \mathrm{W}\right)$ and near the Landes coast $\left(45^{\circ} \mathrm{N}-2^{\circ} \mathrm{W}\right)$, the thermocline appears less marked in the north (Vincent and Kurk, 1969; Koutsikopoulos and Le Cann, 1996); however, temperature can differ by $8-9^{\circ} \mathrm{C}$ between the surface and $\sim 30 \mathrm{~m}$ water depth. The mean SST varies between $15^{\circ} \mathrm{C}$ and $20^{\circ} \mathrm{C}$. When maximum temperatures are reached in August, the mean SST is roughly $\sim 2^{\circ} \mathrm{C}$ higher near $45^{\circ} \mathrm{N}$, than at $47^{\circ} \mathrm{N}$ (along the $200 \mathrm{~m}$ isobath). This north-south difference can be explained partially by the occurrence of greater tidal mixing in the north, but also by less solar radiation and the influence of stronger winds over an extended area of shallow water. Some seasonal thermal fronts can be observed, over the continental shelf. Off western Brittany, the fronts are related to interactions between the topography and the tidal currents (Pingree et al., 1982; Mariette and Le Cann, 1985) whereas, along the northern Armorican slope, they result mainly from mixing induced by internal tides propagating across the shelf-break (e.g. Pingree et al., 1982; Mazé et al., 1986; Le Tareau and Mazé, 1993; Pingree and New, 1995 and Druon et al., 2001). Some local upwellings are observed often along the southern continental shelf, particularly along the Landes coast (Pingree, 1984, Froidefond et al., 1996).

In autumn, the thermocline deepens and, in the shallowest waters, a mean seasonal profile shows a nearly homogeneous water column (Koutsikopoulos and Le Cann, 1996).

\subsection{Haline variability and plumes}

In the oceanic domain of the Bay of Biscay, the water masses of the upper layers (from $100 \mathrm{~m}$ to $600 \mathrm{~m}$ ) have characteristics which are close to those of the North Atlantic Central Water (NACW) with salinity varying from 35.4 to 35.7-35.8 (see reviews of Boucher, 1985 
and Van Aken, 2001). In the coastal domain of the bay, shallower waters $(<200 \mathrm{~m})$ are affected by the freshwater. This influence, characterised by plume features, has been studied using numerical models.

Model simulations, performed over a 7-year period, have highlighted several features of Gironde and Loire plumes (Jégou and Lazure, 1995; Lazure and Jégou, 1998). During winter, vertical salinity stratification is weak on the shelf; it is almost nonexistent. Winds are often from the southwest (downwelling-favourable) and, during periods of high river runoff, plumes spread usually northwards and along-shore. Low-salinity waters are located to the north of each estuary, often inshore of the $50 \mathrm{~m}$ isobath. When the river discharge is reduces and the prevailing winds are from the northwest (upwelling-favourable), the northward spread of plumes may be stopped and driven offshore or southwards; this occurs usually in spring. Such variability has been observed also on NOAA/AVHRR visible and infrared images (Jégou and Lazure, 1995; Froidefond et al., 1998 and Hermida et al., 1998). These simulations have highlighted also the inter-annual fluctuations in the spread of the plumes. Computed near-surface salinity recorded the maximal extension of the freshwater influence, in May 1994 and 1995, when the 34.0 and 34.5 isohalines reached the slope; in comparison, in May 1992 and 1993, they did not reach the 100m isobath. These maximum offshore ranges were linked to exceptionally high runoffs and strong upwelling-favourable winds. Nevertheless, no hydrographical data has been published to confirm these results.

The limited salinity maps available do not represent adequately seasonal variability, nor mesoscale structures (for instance, Koutsikopoulos et al., 1991). Moreover, in most cases, published hydrographical data were collected some considerable time ago and, hence, difficult to interpret. Likewise, since adequate sampling of the area took often several days, such a pattern was insufficiently synoptic to include mesoscale features. In order to understand the 
hydrology of the French continental shelf, knowledge of temperature alone is not sufficient; corresponding salinity data are requested.

\section{Data and Methods}

\subsection{Hydrographical data}

The in-situ hydrographical data for the Bay of Biscay French continental shelf were collected between 1992 and 2000. Relevant cruises are listed in Table 1, selected on the basis of their conductivity/salinity measurements and the areas covered. For simplicity, the French shelf has been divided into 4 numbered areas (Fig. 1).

Table 1: Selected cruises (alphabetically ordered); on the French continental shelf of the Bay of Biscay.

Utilising approximately 25 cruises provides data distributed throughout the entire year, except August. Hence, we can investigate seasonal hydrographical variability. The monthly evolution of haline and thermal stratifications together with that of surface salinities, are examined. Surface temperature charts are not presented here, since they exist elsewhere (Vincent and Kurc, 1969; Vincent, 1973).

Because the data were acquired over 9 years, hydrographic situations for the same month (April, May, June, and September) are compared, in different years, to examine interannual variability. 
Most of the cruises were devoted to fisheries observations: stock estimations and recruitment; as such, they are not all suitable for mesoscale observations. However, MODYCOT (MODelisation of the COasTal DYnamics) cruises cover a large part of the French shelf and were acquired within one week; in comparison with the other available data, they have the highest sampling spatial resolution, with $25-30 \mathrm{~km}$ between CTD casts. Thus, only the MODYCOT data can provide a description of the mesoscale structures.

\subsection{Primary forcing data}

Hydrographic and dynamic variability are strongly linked, as explained previously, to river runoff and wind. Consequently, these will be the primary forcing parameters for this particular data analysis. Annual river runoffs are considered over the last 10 years (Fig.2). The mean annual outflow was $\sim 850 \mathrm{~m}^{3} . \mathrm{s}^{-1}$, with a standard deviation of $\sim 250 \mathrm{~m}^{3} . \mathrm{s}^{-1}$; this represents a significant part of the mean outflow $(\sim 30 \%)$. Such variability is related mainly to

three exceptional annual runoffs: the minimum of $\sim 400 \mathrm{~m}^{3} \cdot \mathrm{s}^{-1}$ in 1990 and 1991 together with the maximum of $\sim 1300 \mathrm{~m}^{3} \cdot \mathrm{s}^{-1}$ in 1994 . The annual mean values show strong inter-annual variability in the river discharges. However, for example, the highest runoff recorded in January-March 1995 is not represented by the 1995 mean outflow. Therefore, an annual mean will not sufficiently explain the inter-annual variability in the monthly salinity distribution; as such, a 3-monthly mean is more suitable. In the Bay of Biscay, river runoffs are generally maximal in winter and minimal in summer.

For the seasonal analysis, annual mean wind trend and speed have been calculated from winds recorded at 4 points along the coast, over a ten-year period. Ten-year means of these winds are represented by Progressive Vector Diagrams (PVD) (Fig. 3). These diagrams 
represent the apparent trajectory that a particle would trace, if it was driven by those mean Eulerian winds. Other wind PVDs (not averaged) have served to analyse mesoscale and interannual variability, but are not shown.

\section{Results}

\subsection{Monthly and seasonal hydrographical variability}

Surface salinity maps and all the available salinity and temperature profiles are presented, for each month in Plate 1. By superimposing the profiles it is possible to estimate the depth of the surface layer, according to salinity and temperature stratification. In order to depict how representative the results are, the number of casts used and the cruise names are indicated. In addition, CTD stations are reported on the salinity maps. The most significant monthly variability diagrams and salinity maps are those for May, June, and September, because at least 3 data sets were used for the calculations and the greatest area was covered. The least significant monthly maps were those for December, January, February and July, with only one data set for each month and a small area covered. Therefore, the maps presented should not be interpreted in isolation. Rather, within the context of the preceding and following maps, they allow trends in the seasonal variability to be estimated.

In relation to the salinity profiles, it can be observed that the variability in surface salinity (from less than 30, to 36) is higher than at $50 \mathrm{~m}(35.0-36.0)$. In deep waters $(>150 \mathrm{~m})$, the salinity varies only from 35.5 to 35.7 over the whole of the year, all over the French shelf, this corresponds to the NACW salinity. Consequently, attention will be focused upon the surface layer $(0-150 \mathrm{~m})$. 
Three seasonal thermal patterns can be inferred, as outlined before:

- From January-April, the water column was homogenous in the temperature. In January and February, only the Gironde and Charente coastal areas were investigated (inshore mid-shelf). Low thermal stratification appeared at the end of April.

- In May, the seasonal thermal stratification became significant within the upper 25 $\mathrm{m}$ of the water column: near the surface, the maximum temperature (Tmax) was $\sim 18^{\circ} \mathrm{C}$; at $50 \mathrm{~m}$ Tmax was $\sim 14^{\circ} \mathrm{C}$. During the following months, the temperature increased in the upper $50 \mathrm{~m}$ whilst, below $100 \mathrm{~m}$, temperatures never exceeded $\sim 13^{\circ} \mathrm{C}$. Between May and September, the seasonal thermocline deepened, except in July, but data are scarce and only cover the Gironde area.

- Between mid-September and December, the thermal stratification was broken down. In September, maximal temperatures were reached at the surface, with 22$24^{\circ} \mathrm{C}$ near the coast and $23.4^{\circ} \mathrm{C}$ at the most edge, near $44^{\circ} \mathrm{N}$. Nevertheless, initial autumn mixing occurred at the end of the month. Some profiles displayed a thermally-homogenous layer that can extend to $50 \mathrm{~m}$, being deeper at stations farthest offshore. From October-November, the temperatures decreased and the thermal homogeneity increased.

These monthly temperatures agree with those found in the literature (Vincent and Kurc, 1969; Vincent, 1973).

Two main seasonal haline patterns can be identified in spring and autumn. Winter and summer cannot be described accurately, because there are insufficient data during these seasons.

- In spring (March-June), the surface salinities were most variable. From March to April, very low salinity $(\mathrm{S}<34)$ was measured near the coast (inshore mid-shelf) and 
some water with salinity above 35 (drawn in dark blue on the salinity maps) was observed offshore from the mid-shelf ( isobath $100 \mathrm{~m})$. Significant variability was induced near the surface (30.0-35.7) and a distinct gradient was observed in the upper $50 \mathrm{~m}$. In May and June, very low salinities are still present, whilst the low salinity waters $(\mathrm{S}<35)$ extended offshore, to beyond the $100 \mathrm{~m}$ isobath. The observed strong haline stratification and variability correspond to winter maximum river discharges.

- From the end of the summer and throughout the autumn (September-November), the salinity profiles displayed less surface variability than in spring. Haline destratification commenced in September, with wind-induced convective mixing: salinity minima were greater (33-34). On the September surface salinity map, to the north of $\sim 46^{\circ} \mathrm{N}$, water with salinity was $\mathrm{S}>35$ was located closest to the coast and replaced water with salinity $\mathrm{S}<34$, as observed in March in a coastal strip some 100 $\mathrm{km}$ in width. Consequently, in this area, salinity increased approximately by $\sim 1 \mathrm{psu}$ (an important variation). Farther offshore from the slope and farther to the south $\sim 46^{\circ} \mathrm{N}$, over the entire shelf width, there was somewhat reduced rise in salinity ( $\mathrm{S} \sim 34-35$, between $44^{\circ} \mathrm{N}$ and $46^{\circ} \mathrm{N}$ ). This increase in salinity, over a greater part of the continental shelf, is linked to a decrease in river runoff.

It may be noted also that, in September, the isohalines run cross-shore indicating that the less saline waters spread offshore. In contrast, on the March-April maps, isohalines were alongshore i.e. the less saline waters remain along the coast. This seasonal variation could be observed for every year for which there are available data, for example, by comparing MODYCOT 98-4 and MODYCOT 99-3 surface salinity maps, acquired in September, with MODYCOT 98-3 and MODYCOT 99-1, acquired in April (not shown). As the decrease of river runoff in summer cannot induce offshore spreading of less salty water, mean annual wind 
conditions are considered. Wind PVDs calculated over the last decade (Fig. 3) at 4 locations along the coast, show a shift of mean direction from south-westerly to north-westerly from March-April; subsequently, to southwesterly from, September-October. Consequently, the April observation is the result of 6 months of southwesterly winds which maintain the less salty water along the coast. In comparison, the September observation is the result of 6 months of northwesterly winds which could move the less salty water offshore. In this way, in summer the offshore spread of less salty water masses can induce lower salinity values; this was the case at the stations located farthest offshore of the Plagia cruise (Fig. 4: station 1 has salinity values lower during summer than in winter and spring). Consequently, the decrease in river runoff and wind can have opposing effects.

For the data presented, the observed temperature distribution can be explained mainly by vertical 1-D processes: heat budget, tidal and convective mixing. In contrast, salinity is a conservative parameter and its distribution is explained by 3-D processes: freshwater discharge and advection by the wind- and density-driven currents. However, such processes do not explain all features such as, for example, the winter surface temperature inversions which are due to 3-D effects. These results have highlighted the trends in seasonal haline variability with relatively high confidence, as at least 3 years of data were used over each 3month season. Nevertheless, the most significant monthly maps used only 4-5 data sets. Significant inter-annual variability could affect those results.

\subsection{Inter-annual variability of the fresh water influence}

In order to highlight the inter-annual variability of surface salinity distribution over the shelf, the April and May surface maps have been selected, because the data sets are available 
for 3 different years. The spreading of low salinity water is investigated by tracing, when possible, the 35 isohaline, as it provides relatively good representation of the low salinity water limit in the April-May period. When water is present with salinity mostly lower than 35 , the 34.5 isohaline is traced instead. Following that, variability in the bottom waters is compared to that on the surface. At depths greater than $150 \mathrm{~m}$, the salinity ranges between 35.5 and 35.7 ; as such, the 35.6 isohaline is traced. In order to explain the variability in the surface salinity distribution, the wind and river runoff for the year in question are considered on a monthly basis.

- April distributions

In April 1992 (Fig. 5a), the low salinity water was the closest to the coast in the vicinity of the Loire and Gironde estuaries (less than $50 \mathrm{~km}$ offshore). The rivers' discharges over the 11 years were lowest between July 1991 and March-April 1992 (Fig. 2). Wind conditions were unexceptional, and, as such, this 9-month period of minimum runoff maintained the low salinity values closest to the coast.

In April 1998, low salinity water spread in a 50-80 km width band all along the French coast. For this intermediate situation, winds were not "upwelling-favourable", but the river runoff in April-June was one of the highest over the 10-year period.

April 1999 was an extreme situation, where the 34.5 isohaline was farther offshore than the 35 isohaline was in 1998. River runoff values were typical. The average wind (at Belle Ile) during MODYCOT cruise (MODYCOT 99-1, 07-13/04/99) was of medium strength $\left(7 \mathrm{~m} . \mathrm{s}^{-1}\right)$ and favourable to upwelling (direction WNW, 290 ${ }^{\circ}$ ). These winds, established in less than ten days, moved the low salinity waters offshore, increasing the extension of the 34.5 isohaline.

- May distributions

In May 1994 (Fig. 5b) the most striking observation was the spreading, far offshore, of some waters with salinity lower than 34.5 . Salinity values greater than 35.0 were scarce, 
especially in the southern area $\left(44-45^{\circ} \mathrm{N}\right)$; hence, they are not represented here. This situation occurred just after the period of highest winter discharges of both of the rivers, over the 11 years. This observation validates the numerical model results of Lazure and Jégou (1998), where a similar extension of the less salty water was shown for the same period.

In May 1997, the low salinity water remained near the coast, but to a lesser degree than in April 1992. This pattern could be linked to river runoff, as it was the lowest recorded in the March-June period, over the 10 years.

In May 1998, the salinity distribution was similar to that for April 1998, in the Landes and Gironde areas (no data are available for the northern area). The distribution fell between the two preceding ones (May 1994 and May 1992). The Loire discharge in April-June was as high in 1998 as in 1994. The Gironde discharge, although lower, was amongst the highest overall. The wind was also "upwelling-favourable" (monthly average: $4.2 \mathrm{~m} . \mathrm{s}^{-1}, 27^{\circ}$ ). Explaining which of the two forcings was dominant is not yet possible. Note that low salinity water was located not as far offshore compared to 1994. Consequently, excessive river runoff during the $\sim 5$ months before May 1994 (the highest over the 10 years) could have more influence than the synergy of a high monthly runoff and an "upwelling-favourable" wind of May 1998.

- Vertical variability

In the vertical, low salinity water $(\mathrm{S}<35)$ extended in a $\sim 20-40 \mathrm{~m}$ layer from the surface, just above the halocline; this was $\sim 10 \mathrm{~m}$ thick, with a minimum vertical gradient of $\sim 0.05$ psu. $\mathrm{m}^{-1}$. Below the halocline, the bottom situation was less variable (Fig. 5c) as expected from the Plate 1 profiles. On the bottom map, the 35.6 isohaline was in nearly the same location in the southern area (Adour), in April 1998 and 1999. In the Gironde, Loire and Brittany areas, its position varied only by $\sim 50 \mathrm{~km}$. 


\subsection{Mesoscale structures}

Here, mesoscale phenomena refer mainly to wind-induced upwellings, river plume fluctuations, lower salinity water lenses and the cold pool. Several examples of each phenomenon are available and are listed in Table 2. Nevertheless, they cannot all be shown (for reasons of space). Hence, we will present the most representative situations that are well described by the MODYCOT 97-1, MODYCOT 98-4, and MODYCOT 99-3 results.

Table 2: Cruises on which mesoscale structures were observed

\subsubsection{Southern Brittany upwelling}

Southern Brittany upwelling has not been described before in the literature. A typical example is provided on the MODYCOT 97-1 (June 1997) surface temperature map (Fig. 6a). A reduction of $0.5-0.6^{\circ} \mathrm{C}$ is observed at the surface, over the $\sim 30 \mathrm{~km}$ between the most coastal station $\left(14.9^{\circ} \mathrm{C}\right)$ and the next offshore station $\left(15.5^{\circ} \mathrm{C}\right)$ (Fig. $\left.6 \mathrm{a} \& \mathrm{~b}\right)$. At $20 \mathrm{~m}$, the horizontal thermal gradient was stronger, with more than $1.3^{\circ} \mathrm{C}$ change over $\sim 30 \mathrm{~km}$. This upwelling induced $14^{\circ} \mathrm{C}$ water to rise from $\sim 40 \mathrm{~m}$ to $\sim 20 \mathrm{~m}$, over $\sim 20 \mathrm{~km}$. It occurred during a northwesterly wind event $\left(\sim 8 \mathrm{~m} \cdot \mathrm{s}^{-1}\right)$, starting one week before the cruise began.

These structures were observed also on infrared images including that of $18^{\text {th }}$ September 1998 (fig. 7, one week after MODYCOT 98-4). On this image, the coldest surface water $\left(\mathrm{T}<16^{\circ} \mathrm{C}\right)$ lies along the southern Brittany coast. Slightly warmer water $\left(\mathrm{T}<17^{\circ} \mathrm{C}\right)$ was observed up to the mid-shelf, $\sim 100 \mathrm{~km}$ offshore from southern Brittany and along the Vendée coast, to the north of the Gironde estuary. On the September 1998 salinity maps (at the surface and at $20 \mathrm{~m}$, on Fig. 8), the southern Brittany upwelling is indicated also by some 
35.5-35.6 salinities surrounded by 35.4-35.5 values. Over this period, northwesterly (8-12 $\mathrm{m} . \mathrm{s}^{-1}$ ) winds lasted for 2 days.

During these observations, at least, the southern Brittany upwellings were linked to north-northwesterly winds. In this coastal area, the tidal currents are weak (Pingree, et al., 1982) allowing strong stratification and the development of an Ekman layer, which is well separated from the bottom layer. Unfortunately, in the across-shore direction, the upwellings are only indicated at one or two stations. A sampling interval of 30-50 km is not well adapted to sample a phenomenon of some $\sim 50 \mathrm{~km}$ in width. Consequently, the specified gradients only reflect a "rough" estimation.

\subsubsection{Lower salinity lenses}

On the MODYCOT 98-4 salinity distributions (Fig. 8, representing September 1998) a lower salinity lens (L on Fig. 8) is present in a surface layer down to at least $20 \mathrm{~m}$, in the Gironde area at $\sim 46^{\circ}$ N. It corresponds to salinity values lower than 35.1 surrounded by 35.1 35.4 salinities. On the vertical transects (Fig. 9), the isolines deepen towards the centre in the top $30 \mathrm{~m}$. Its diameter reaches $\sim 80 \mathrm{~km}$, considering the 35.1-35.2 isohalines. Near the surface, horizontal increments of $\sim-0.3 \mathrm{psu}, 1.3^{\circ} \mathrm{C}$ and -0.5 in density are observed, between the most coastal CTD station (P) and the following station (Q) 40 km offshore (fig. 9). Note that a crosshore transect was preferred to an along-shore transect because it was performed in only a single day, instead of the 5 days needed for the along-shore transect. The $\sim 40 \mathrm{~km}$ sampling interval is inadequate for interpolation. $\mathrm{L}$ is observed also on the $18^{\text {th }}$ September image (Fig. 7), which is the first cloud-free scene where $\mathrm{L}$ is visible, one week after the in-situ measurements. Thus, this lens can persist for at least one week. Its generation may be due to NW wind pushing the less salty water offshore, which is then isolated by deeper and saltier 
water rising near the coast. CTD stations corresponding to the lens L were performed on the evening of $11^{\text {th }}$ and on $12^{\text {th }}$ September, accompanied by NW winds (8-12 m.s - $\left.^{-1}\right)$ established from midday on $11^{\text {th }}$ September.

Lower salinity lenses sampled during MODYCOT 99-1 and 99-2 (April and June 1999, respectively) were observed also during "upwelling-favourable" wind events and show similar patterns.

In view of these observations, lower salinity lenses appear to be generated when winds are "upwelling-favourable", pushing less salty water offshore. This hypothesis is consistent with the results of Froidefond et al. (1996). A less salty body ( $<<33.4 \mathrm{psu}$ ) was observed $\sim 30$ $\mathrm{km}$ offshore from the Landes coast, in July 1989, in the surface layer (5 m) during a NW upwelling-favourable wind event. It was assumed that this less salty water originated from the Gironde. Moreover, this hypothesis is consistent with the Chen et al. (1999) simulations applied to the eastern coast of the United States (South Atlantic Bight $27^{\circ} \mathrm{N}-35^{\circ} \mathrm{N}$ ). These investigators could reproduce the formation of lower salinity lenses when winds were "upwelling- favourable". The dynamic consequences of these structures are suggested by the vertical transect shown in Figure 9. Isolines deepening towards the centre correspond to the signature of an anticyclonic eddy, within the context of geostrophic approximations. The induced geostrophic current is estimated to be $3 \mathrm{~cm} \cdot \mathrm{s}^{-1}$. This estimation might be strongly biased, because L is covered by only 3 profiles, each about $40 \mathrm{~km}$ apart. Finer-resolution current measurements are needed.

Some lower salinity lenses have been observed also at intermediate depth, near $40 \mathrm{~m}$, but not at the surface (MODYCOT 99-2, not shown, and MODYCOT 99-3). During MODYCOT 992, some less salty water $(\mathrm{S}<35.1)$ spread over $200 \mathrm{~km}$ offshore, from the Loire - Vilaine coast. During MODYCOT 99-3, a lens appeared 100-150 km off the Loire and Vendée coasts and 
appeared to extend as far as the Gironde area. This could mean that water masses from the Gironde estuary can reach the Loire's offshore zone, and northward currents should be observed; thid is suggested by Castaing's $(1984,1985)$ surface drifting buoy trajectories, between the Gironde and the Loire estuaries. No upwelling was observed at that time and the associated wind speed was low $\left(2-5 \mathrm{~m} \cdot \mathrm{s}^{-1}\right)$. These intermediate lenses may be an old stage of surface less salty surface water, which sunk; therefore, different mechanisms may be responsible for generating lower salinity lenses.

\subsubsection{Cold pool}

In September 1998 (MODYCOT 98-4), the cold pool (CP) was characterised on the vertical transect (Fig. 10a) and on the bottom temperature map (Fig. 10b), by temperatures varying from $12.0-12.2^{\circ} \mathrm{C}$, from $\sim 40-50 \mathrm{~m}$ to the bottom. It can induce a horizontal thermal increment of $0.5^{\circ} \mathrm{C}$, over $\sim 25 \mathrm{~km}$ at $60 \mathrm{~m}$ (from $12.2-12.7^{\circ} \mathrm{C}$ isotherms). The $\mathrm{CP}$ was sampled again one year later, during the MODYCOT 99-3 cruise, at almost the same sampling points. Compared with the 1998 situation, in 1999 the cold pool was largest, according to the $12.2^{\circ} \mathrm{C}$ isotherm on the vertical transect (Fig. 11a) and on the bottom temperature map (Fig.11b). Its extent more than doubled on a NW-SE axis, in 1999 . It was also colder with $11.7-12.0^{\circ} \mathrm{C}$, from $\sim 50 \mathrm{~m}$ to the bottom. The vertical thermal gradient was also greater in 1999 , than in 1998. This variability cannot be due to a sampling problem, although the cold pool stations were investigated over several days (3-4 days); this is because, near the bottom, the high frequency variability is expected to be negligible. This pattern could be linked to the wind effect: September 1998's wind event induced significant upwelling and probably increased vertical mixing, thus reducing thermal stratification. 
In contrast with the lower salinity lens, the dynamic consequence of this structure should be a cyclonic circulation (doming isolines), as is the case in the North Sea (Brown et al., 1999) where a large CP (500 km wide) can create a velocity in excess of $\sim 0.1 \mathrm{~m} . \mathrm{s}^{-1}$ (from drifter trajectories and geostrophic calculations). The density gradients involved in the North Sea cold pool seem to be similar to those of the Bay of Biscay $C P\left(\Delta \sigma_{\mathrm{T}} \sim 2\right.$ in $20 \mathrm{~m}$, not shown), so a similar excess velocity could be expected. In that case, since the surface front (for example, due to a lens) generally does not correspond to the bottom front, the water column would display some baroclinic features. Cold pool systems may also have implications for planktonic organisms as retention structures, as in the Irish sea (Hill, 1993, 1996; Horsburgh et al., 2000)

\section{Conclusions}

Wind events on time-scales of around 15 days (such as in April 1999), together with river runoff on time-scales from 3-6 months, are responsible for the monthly surface situation and contribute to its inter-annual variability. Also, on these scales, river runoffs and winds drive the generation of mesoscale surface structures, which contribute significantly to the monthly haline surface distribution and, as such to inter-annual variability. Moreover, because the wind and the river discharge vary seasonally, mesoscale structures should display a seasonal variability, as suggested by Koutsikopoulos and Le Cann (1996). In contrast, wind and river runoff have limited influence on the deepest layers, where the water properties are close to those of NACW.

These observations, at different spatial and temporal scales (inter-annual, seasonal and mesoscale), demonstrate strong variability of the salinity distribution and an interdependence 
of the processes on those scales. This observation highlights also the importance of mesoscale variability on the waters of the Bay of Biscay continental shelf, as it participates in the larger scale features. Consequently, efforts should be devoted to a better understanding of this variability. Data sets used in this contribution indicate the need for higher sampling resolution. In order to sample lower salinity lenses or upwellings, a maximum sampling interval of $\sim 10 \mathrm{~km}$ is necessary; likewise, the area concerned must be studied over a single day, because of the rapid influence of storms. In addition, our seasonal analysis, based upon 3-4 years of measurements, may be distorted strongly by inter-annual variability and mesoscale structures. As such, the calculated salinity maps may be not representative of the true seasonal cycle. More measurements are necessary, over several years and giving priority to months where the available data are scarcest (December-February and July-August). Investigation of the hydrographical and dynamic variability of this coastal area has numerous other applications. These can be environmental, for instance, the cadmium transport from the Gironde to the Marenne-Oleron bay (Boutier et al., 2000). Likewise, biological, for instance, in winter the only possible stratification is haline and could isolate a surface layer in which a bloom could develop, if enough light is available (Labry et al., 2001; Lampert et al., 2002). Lower salinity lenses are believed to have the dynamic structure of eddies and could stimulate population growth, through confinement, as shown elsewhere in Alaska (Schumacher et al., 1993). We hope to be able to verify this interpretation for the Bay of Biscay shelf, with the data now being collected.

\section{Acknowledgements}

We thank EPSHOM/CMO (Brest), Ecohal/IFREMER (Nantes) and the SISMER, for permitting us to use the hydrographical data presented here, as well as the Plymouth Marine Laboratory Remote Sensing Group, UK (http://www.npm.ac.uk/rsdas/) for the provision of 
infrared images and Schlitzer, R., for the Ocean Data View freeware program (http:/www.awi-bremerhaven.de/GEO/ODV/2001). For the river runoff data, we thank the DIREN Centre (Service du Bassin Loire-Bretagne), the Bordeaux Port Authority, the French Ministry of the Environment's national database for hydrometry and hydrology. We thank F. Vandermeirsch for its participation. We gratefully thank also the reviewers for their useful comments. 


\section{References}

Boutier, B., Chiffoleau, J.F., Gonzalez, J.L., Lazure, P., Auger, D., Truquet, I., 2000. Influence of the Gironde estuary outputs on cadmium concentrations in the coastal waters: consequences on the Marennes-Oleron bay (France). Oceanol. Acta 23 (7-suppl.), 745-757.

Boucher, J., 1985. Caractéristiques physiques et biologiques. In Laubier L. and Monniot C. (eds.): Peuplements profonds du Golfe de Gascogne, 25-42, IFREMER ed.

Brown, J., Hill, A.E., Fernand, L., Horsburgh, J., 1999. Observations of a seasonal Jet-like circulation at the central North Sea cold pool margin. Estuarine, Coastal and Shelf Science 48, 343-355.

Castaing, P. 1984. Courantologie de dérive dans les zones côtières à l'aide de bouées positionnées par satellite (Système ARGOS). Dix-huitième Journées de l'hydrologie, Marseille, 8p.

Castaing, P., 1985. Mesure of drifting currents in the coastal zone of the Bay of Biscay between the Gironde and the Loire estuary inlets. Bull. Inst. Géol. Bassin d'Aquitaine 38, 517.

Chen, C., Zhen, L., Blanton, J.O., 1999. Physical processes controlling the formation, evolution, and perturbation of the low-salinity front in the inner shelf off the southeastern United States: A modelling study. J. Geophys. Res. 104 (C1), 1259-1288.

Druon, J.N., Langlois, G., Le Fèvre, J., 2001. Simulating vertical mixing in a shelf-break region: addition of a shear instability model, accounting for the overall effect of internal tides, on top of a one-dimensional turbulence closure mixed layer model. Cont. Shelf Res. 21, 423-454.

Froidefond, J.M., Castaing, P., Jouanneau, J.M., 1996. Distribution of suspended matter in a coastal upwelling area. Satellite data and in situ measurements. J. Mar. Sys. 8, 91-105.

Froidefond, J.M., Jégou, A.M, Hermida, J., Lazure, P., Castaing, P, 1998. Variabilité du panache turbide de la Gironde par télédétection. Effets des facteurs climatiques. Oceanol. Acta 21 (2), 191-207.

Frouin, R., Fiuza, A.F.G., Ambar, I., Boyd, T.J., 1990. Observations of a poleward surface current off the coasts of Portugal and Spain during winter. J. Geophys. Res. 95 (C1), 679-691.

Hermida, J., Lazure, P., Froidefond, J.M., Jégou, A.M., Castaing, P., 1998. La dispersion des apports de la Gironde sur le plateau continental. Données in situ, satellitales et numériques. Oceanol. Acta 21 (2), 209-221.

Hill, A.E., 1993. Seasonal gyres in shelf seas. Ann. Geophys. 11 (11-12), 1130-1137.

Hill, A.E., 1996. Spin-down and the dynamics of dense pool gyres in shallow seas. J. Mar. Res. 54 (3), 471-486. 
Horsburgh, K.J., Hill, A.E., Brown, J., Fernand, L., Garvine, R.W., 2000. Seasonal evolution of the cold pool gyre in the western Irish Sea. Prog. Oceanogr. 46 (1), 1-58.

Jégou, A.M., Lazure, P., 1995. Quelques aspects de la circulation sur le plateau atlantique, in : Acta del IV Coloquio Internacional Sobre Oceanografica del Golfo de Vizcaya, 96-106.

Koutsikopoulos, C., Le Cann, B., 1996. Physical processes and hydrological structures related to the Bay of Biscay anchovy. Sci.Mar. 60 (2-Supp.), 9-19.

Koutiskopoulos, C., Fortier, L., Gagne, J.A., 1991. Cross-shelf dispersion of Dover sole (Solea solea) eggs and larvae in Biscay Bay and recruitment to inshore nurseries. J. Plankton Res. 13 (5), 923-945.

Koutsikopoulos, C., Beillois, P., Leroy, C., Taillefer, F., 1998. Temporal trends and spatial structures of the sea surface temperature in the bay of Biscay. Oceanol. Acta 21 (2), 335-344.

Labry, C., Herbland, A., Delmas, D., Laborde, P., Lazure, P., Froidefond, J.M., Jégou, A.M., Sautour, B., 2001. Initiation of winter phytoplankton blooms within the Gironde plume waters in the Bay of Biscay. Mar. Ecol. Prog. Ser. 212, 117-130.

Lampert, L., Queguiner, B., Labasque, T., Pichon, A., Lebreton, N., 2002. Spatial variability of phytoplankton composition and biomass on the eastern continental shelf of the Bay of Biscay (north-east Atlantic Ocean). Evidence for a bloom of Emiliania huxleyi (Prymnesiophyceae) in spring 1998. Cont. Shelf Res. 22, 1225-1247.

Lazure, P. and Jégou, A.M., 1998. 3D modelling of seasonal evolution of Loire and Gironde plumes on Biscay Bay continental shelf. Oceanol. Acta 21 (2), 165-177.

Le Cann, B., 1988. Dépouillement des données de courants, de température et d'hydrologie, Ciresol, Scientific Report N³, Université de Bretagne occidentale, 136p.

Le Cann, B., 1982. Evolution annuelle de la structure hydrologique du plateau continental au sud de la Bretagne : modélisation numérique. Université de Bretagne occidentale, $\mathrm{PhD}$ thesis in physical oceanography, 252p.

Le Cann, B., 1990. Barotropic tidal dynamics of the Bay of Biscay shelf: observations, numerical modelling and physical interpretation. Cont. Shelf Res. 10 (8), 723-758.

Le Cann, B. and Pingree, R., 1995. Circulation dans le Golfe de Gascogne: une revue des travaux récents, in Acta del IV Coloquio Internacional Sobre Oceanografica del Golfo de Vizcaya, 217-234.

Le Cann, B., Girardot, J.P., Poulard, J.C., 1997. SEFOS Drifting Buoys in the Bay of Biscay area: Final report, January 1997

Le Fevre, J., 1986. Aspects of the biology of frontal systems. Adv. Mar. Biol. 23, 164-299.

Le Tareau, J.Y. and Mazé, R., 1993. Storm effects on the baroclinic tidal field in the Bay of Biscay. J. Mar. Sys. 4, 327-347. 
Mariette, V. and Le Cann, B., 1985. Simulation of the formation of the Ushant thermal front. Cont. Shelf Res. 4 (6), 637-660.

Mazé, R., Camus, Y., Le Tareau, J.Y., 1986. Formation de gradients thermiques à la surface de l'océan, au-dessus d'un talus, par interaction entre les ondes internes et le mélange dû au vent. J. Cons. Int. Explor. Mer 42, 221-240.

Motos L., Uriarte A., Valencia V., 1996. The spawning environment of the Bay of Biscay anchovy (Engraulis encrasicolus L.). Sci Mar. 60 (sup. 2), 117-140.

Pingree, R.D., 1984. Some applications of remote sensing to studies in the Bay of Biscay, Celtic sea and English channel. Remote sensing of the shelf sea hydrodynamics, Proceeding of the $15^{\text {th }}$ International Liege Collocium on Ocean Hydrodynamics. Elsevier Oceanography series $38,285-315$.

Pingree, R.D., 1994. Winter warming in the southern Bay of Biscay and Lagrangian eddy kinematics from a deep-drogued Argos buoy. J. mar. biol. Ass. U.K. 74, 107-128.

Pingree, R. D. and Le Cann, B., 1989. Celtic and Armorican slope and residual currents. Prog. Oceanog. 23, 303-338.

Pingree, R. D. and Le Cann, B., 1990. Structure, strength and seasonality of the slope currents in the Bay of Biscay region. J. mar. biol. Ass. U.K. 70, 857-885.

Pingree, R. D. and Le Cann, B., 1992. Three anticyclonic Slope Water Oceanic eDDIES (SWODDIES) in the southern Bay of Biscayin 1990. Deep-Sea Res. 39 (7/8), 1147-1175.

Pingree, R. D. and New, A.L., 1995. Structure, seasonal development and sunglint spatial coherence of the internal tide on the Celtic and Armorican shelves and in the Bay of Biscay. Deep-Sea Res. 42 (2), 245-284.

Pingree, R.D., Mardell, G.D., Holligan, P.M., Griffiths, D.K., Smithers, J., 1982. Celtic Sea and Armorican current structure and the vertical distributions of temperature and chlorophyll. Cont. Shelf Res. 1 (1), 99-116.

Sánchez F. and Gil J. 2000. Hydrographic mesoscale structures and Poleward Current as a determinant of hake (Merluccius merluccius) recruitment in southern Bay of Biscay, ICES Journal of Marine Science 57 (1), 152-170

Schumacher, J.D., Stabeno, P.J., Bograd S.J., 1993. Characteristics of an eddy over the continental shelf: Shelikov Strait, Alaska. J. Geophys. Res. 98, pp 8395-8404.

Van Aken H., 2001. The hydrography of the mid-latitude Northeast Atlantic Ocean. Part III: the subducted thermocline water mass. Deep-Sea Res. I 48, 237-267.

Vincent A., 1973. Les variations de la situation thermique dans le Golfe de Gascogne en 1969 et 1979. Rev. Trav. Inst. Pêches marit. 37 (1), 5-18.

Vincent, A. and Kurc, G., 1969. Hydrologie, variations saisonnières de la situation thermique du Golfe de Gascogne en 1967. Rev. Trav. Inst. Pêches marit. 33(1), 79-96. 


\section{Legend:}

Fig. 1: French continental shelf of the Bay of Biscay, arbitrarily divided into 4 areas.

Area $1=$ Brittany area, area 2= Loire area, area 3= Gironde area, area 4= Landes area. River names are in black with a grey background. Glenan, Belle Ile, Oleron, are French islands. Loire, Charente, Gironde, Adour are rivers. Dotted line is $100 \mathrm{~m}$ isobath.

Fig. 2: Mean outflow of the Loire and the Gironde every 3 months and mean annual outflow.

Fig. 3: Progressive Vector Diagram (PVD) of the annual mean of winds recorded at Le Talus (Belle-île), Chassiron, Cap Ferret and Soccoa between 1989 and 1999 (Meteo-France). Numbered points correspond to the first day of each month.

Plate 1: Monthly variability of the salinity and temperature profiles and of the surface salinity distribution, displayed by 1992-2000 hydrographical data. On surface salinity maps, the blue isohaline is $\mathrm{S}=34$, red one is $\mathrm{S}=35$.

Fig. 4: Salinity trend over time off the Gironde estuary from February 1999 to October 1999 at 4 stations on the Plagia cruises.

Fig. 5: Inter-annual variability of the low salinity $(S<35)$ water extent near the surface in April (a), May (b) and near the bottom (c).

Fig. 6: Southern Brittany upwelling observed during the MODYCOT 97-1 cruise (June 1997) on a surface temperature map (a) and on a vertical temperature transect (b).

Fig. 7: NOAA/AVHRR infrared image on $18^{\text {th }}$ September 1998 (from PML) and sampling stations of the MODYCOT 98-4 survey. L= lower salinity lens, UPW= southern Brittany upwelling.

Fig. 8: Surface (a) and 20m (b) salinity maps calculated from the MODYCOT 98-4 survey (September 1998). L= lower salinity lens.

Fig. 9: Salinity (a) and Sigma-T (b) vertical transect across the lens L during MODYCOT 98-4 survey (September 1998). The colour of the sampling points (c) corresponds to the sampling date in Julian days. P and Q are two CTD stations.

Fig. 10: Vertical temperature transect (a) and bottom temperature map (b) during the MODYCOT 98-4 cruise (September 1998). $\mathrm{CP}=\mathrm{Cold} \mathrm{Pool}, \mathrm{L}=$ lower salinity lens. Temperature colour scales are adjusted differently on the vertical and horizontal representations due to different thermal dynamics, but they can be compared with Fig. 11.

Fig.11: Vertical temperature transect (a) and bottom temperature map (b) during the MODYCOT 99-3 cruise (September 1999). CP= Cold Pool. Temperature colour scales are adjusted differently on the vertical and horizontal representations due to different thermal dynamics, but can be compared with Fig. 10. 


\begin{tabular}{|l|l|l|l|l|}
\hline Cruises & Date dd/mm/yy & organisation & $\begin{array}{l}\text { numbers of } \\
\text { CTD casts } \\
\text { used }\end{array}$ & $\begin{array}{l}\text { areas mainly } \\
\text { sampled } \\
\text { (Fig.1) }\end{array}$ \\
\hline BIOMET2 & $09-12 / 01 / 98$ & IFREMER/SISMER & 34 & 3 \\
BIOMET3 & $03-06 / 03 / 98$ & IFREMER/SISMER & 30 & 3 \\
DAAG 92 & $13-30 / 04 / 92$ & IFREMER/SISMER & 73 & 3,4 \\
ERAG 93 & $04-23 / 06 / 93$ & IFREMER/SISMER & 89 & 2,3 \\
ERAG +AGIR 94 & $24 / 04 / 94-05 / 06 / 94$ & IFREMER/SISMER & 168 & $2,3,4$ \\
EVHOE 927 & $17 / 09 / 92-31 / 10 / 92$ & IFREMER/SISMER & 155 & $1,2,3,4$ \\
EVHOE 948 & $24 / 09 / 94-05 / 11 / 94$ & IFREMER/SISMER & 137 & $1,2,3,4$ \\
EVHOE 959 & $06 / 11 / 95-12 / 12 / 95$ & IFREMER/SISMER & 136 & $1,2,3,4$ \\
MODYCOT 97-1 & $27-29 / 06 / 97$ & EPSHOM/CMO & 20 & 1,2 \\
MODYCOT 97-2 & $15-16 / 12 / 97$ & EPSHOM/CMO & 12 & 2 \\
MODYCOT 98-3 & $22-27 / 04 / 98$ & EPSHOM/CMO & 47 & $1,2,3,4$ \\
MODYCOT 98-4 & $07-16 / 09 / 98$ & EPSHOM/CMO & 38 & $1,2,3,4$ \\
MODYCOT 99-1 & $07-13 / 04 / 99$ & EPSHOM/CMO & 35 & $1,2,3,4$ \\
MODYCOT 99-2 & $07-15 / 06 / 99$ & EPSHOM/CMO & 38 & $1,2,3,4$ \\
MODYCOT 99-3 & $07-14 / 09 / 99$ & EPSHOM/CMO & 46 & $1,2,3,4$ \\
MODYCOT 00-1 & $01-06 / 03 / 00$ & EPSHOM/CMO & 41 & $1,2,3,4$ \\
OLMAC 92 & $01-14 / 06 / 92$ & IFREMER/SISMER & 18 & $1,2,3$ \\
PEGASE 97 & $06 / 05 / 97-03 / 06 / 97$ & IFREMER/SISMER & 107 & $2,3,4$ \\
PEGASE 98 & $20 / 05 / 98-21 / 06 / 98$ & IFREMER/SISMER & 97 & 3,4 \\
PLAGIA 1 & $20 / 02 / 99-01 / 03 / 99$ & IFREMER/SISMER & 30 & 3 \\
PLAGIA 2 & $20 / 04 / 99-01 / 05 / 99$ & IFREMER/SISMER & 30 & 3 \\
PLAGIA 3 & $20 / 05 / 99-01 / 06 / 99$ & IFREMER/SISMER & 30 & 3 \\
PLAGIA 4 & $22 / 06 / 99-25 / 06 / 99$ & IFREMER/SISMER & 30 & 3 \\
PLAGIA 5 & $12 / 07 / 99-15 / 07 / 99$ & IFREMER/SISMER & 30 & 3 \\
PLAGIA 6 & $04-07 / 10 / 99$ & IFREMER/SISMER & 30 & 3 \\
\hline Tate 1: Sected & \\
\hline
\end{tabular}

Table 1: Selected cruises (alphabetically ordered), on the French continental shelf of the Bay of Biscay 


\begin{tabular}{|l|l|l|}
\hline Lower salinity lenses & Upwellings & Cold pool \\
\hline MODYCOT 98-4 : surface-40 m (Sept. 98) & MODYCOT 97-1 (June 97) & MODYCOT 98-4 (Sept. 98) \\
MODYCOT 99-1 : surface-30 m (Apr. 99) & MODYCOT 98-4 (Sept. 98) & MODYCOT 99-2 (Apr. 99) \\
MODYCOT 99-2: surface-25 m (June 99) & & MODYCOT 99-3 (Sept. 99) \\
MODYCOT 99-3: 30-40 m (Sept.99) & & \\
\hline
\end{tabular}

Table 2: Cruises on which mesoscale structures were observed 
FRENCH CONTINENTAL SHELF OF THE BAY OF BISCAY

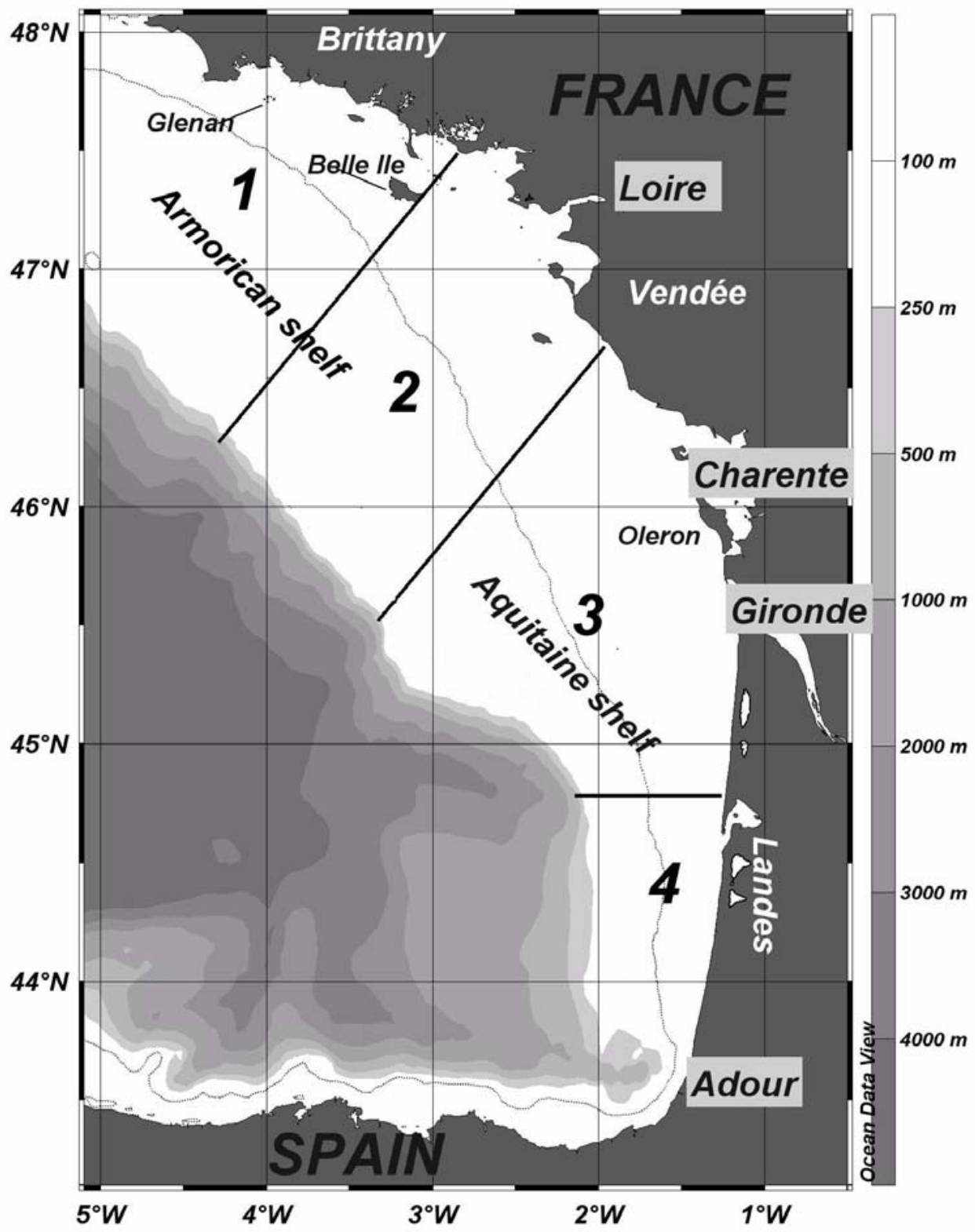

Figure 1 
Mean outflow of the Loire and of Gironde every 3 months (1990-2000)

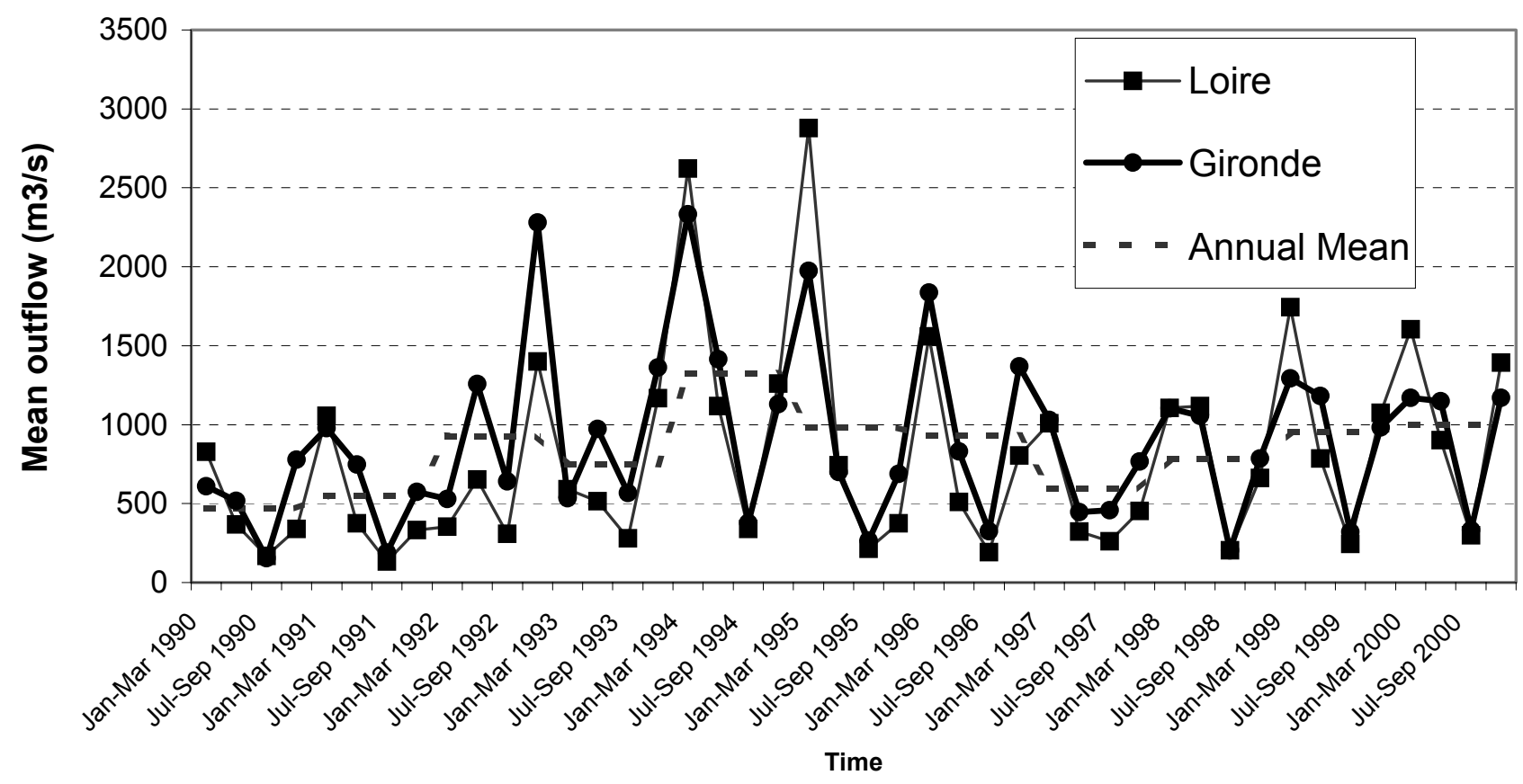

Figure 2 
Progressive Vector Diagram OF THE ANNUAL MEAN WIND FROM 1989-1999 RECORDS
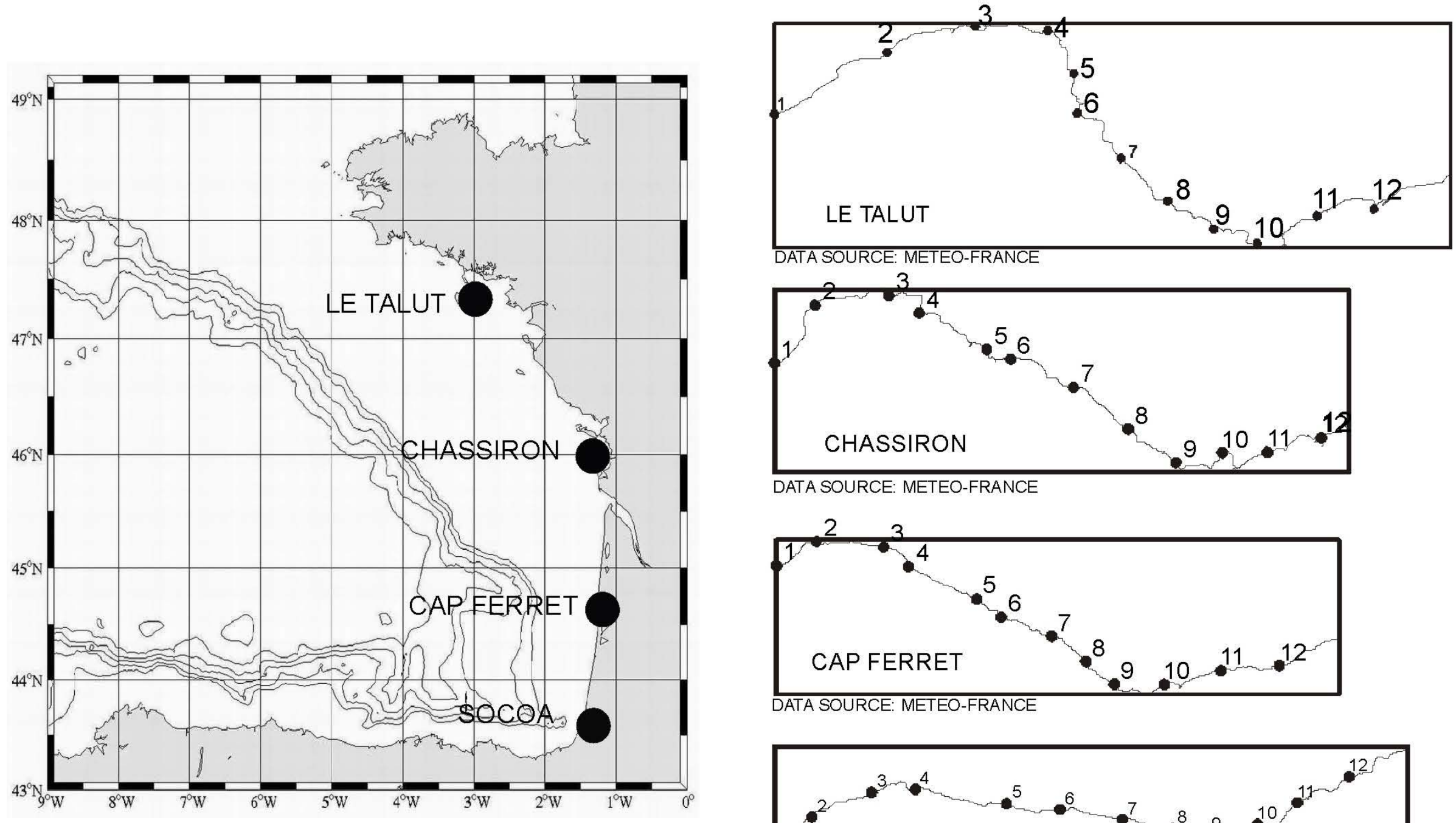

DATA SOURCE: METEO-FRANCE
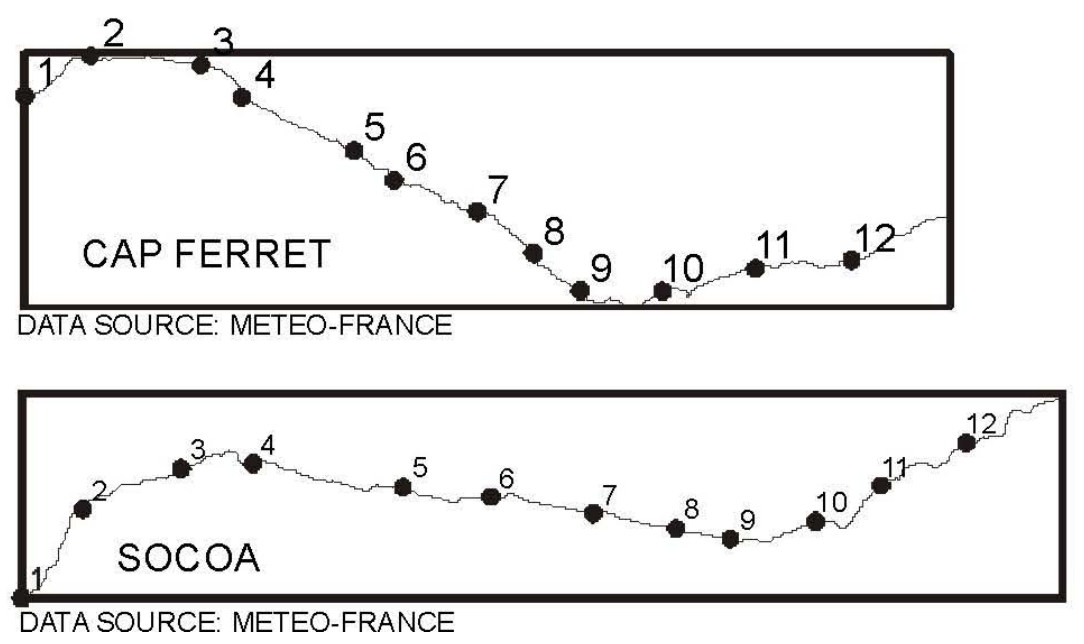

Figure 3 
TEMPORAL EVOLUTION OF THE SALINITY OFFSHORE THE GIRONDE ESTUARY
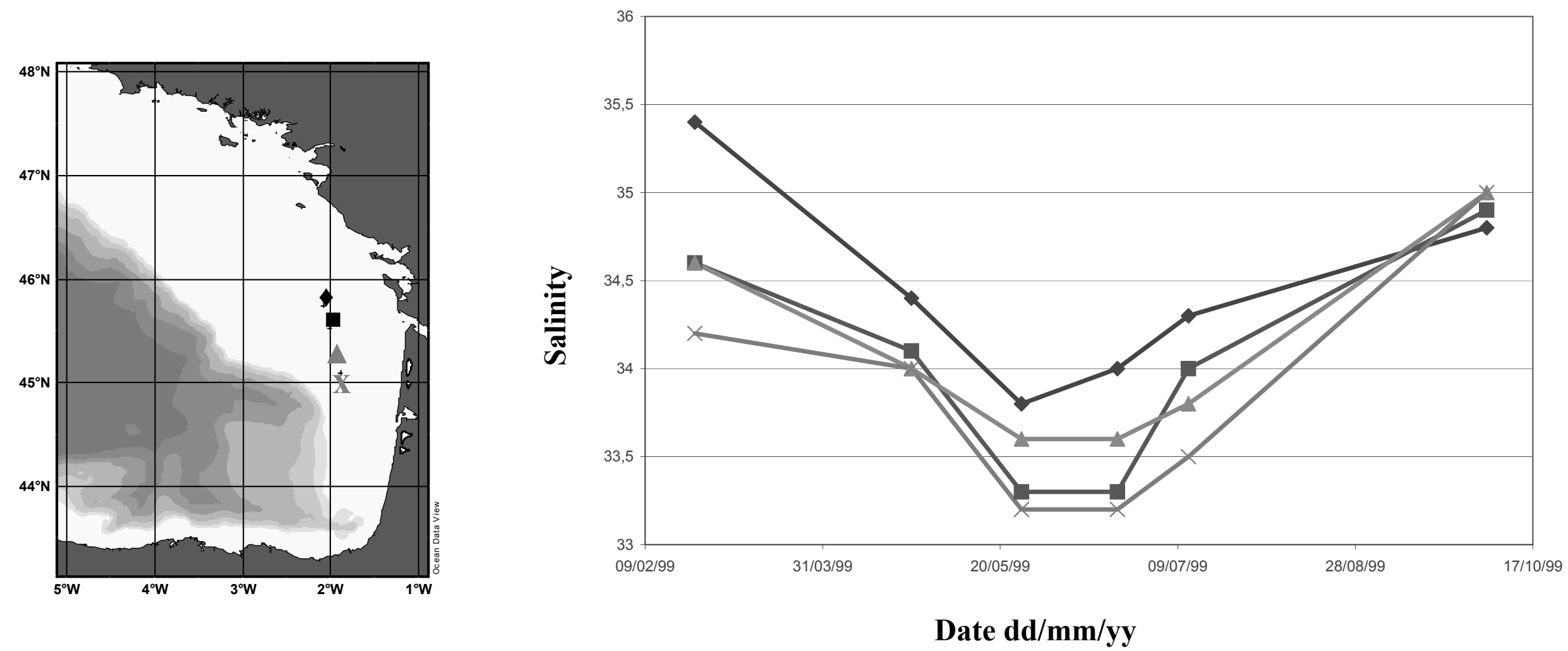

Figure 4 
INTER-ANNUAL VARIABILITY

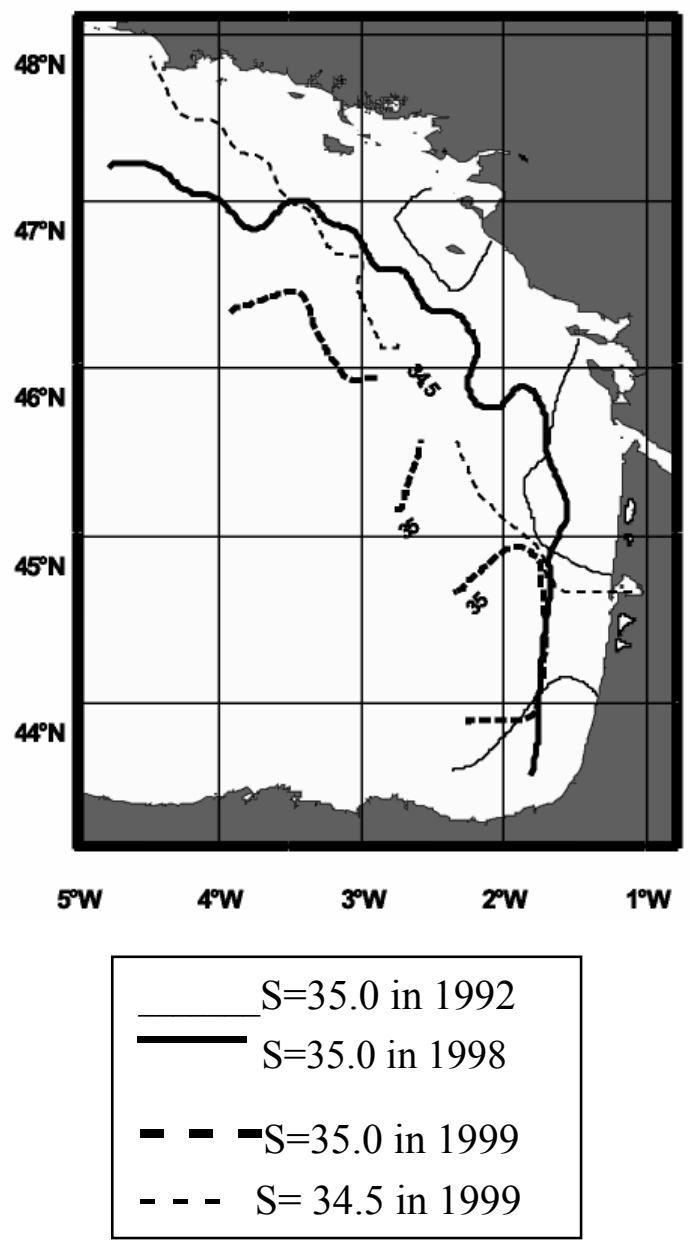

a/ Surface salinity in April

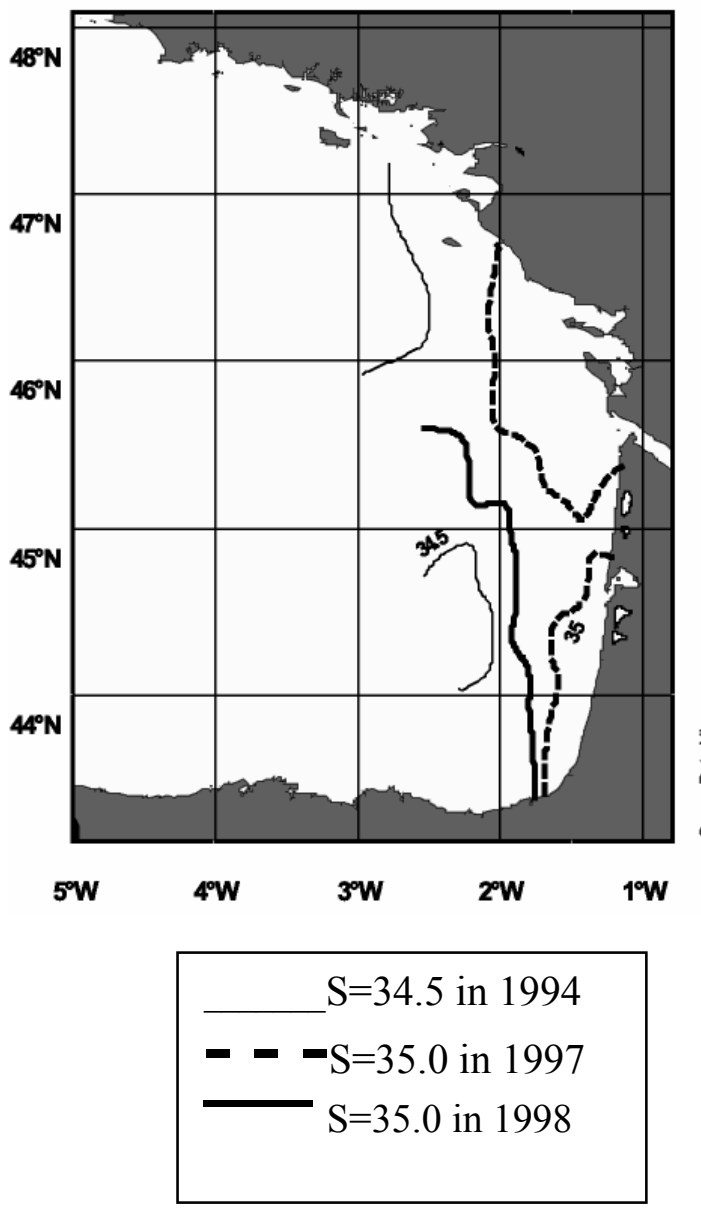

b/ Surface salinity in May

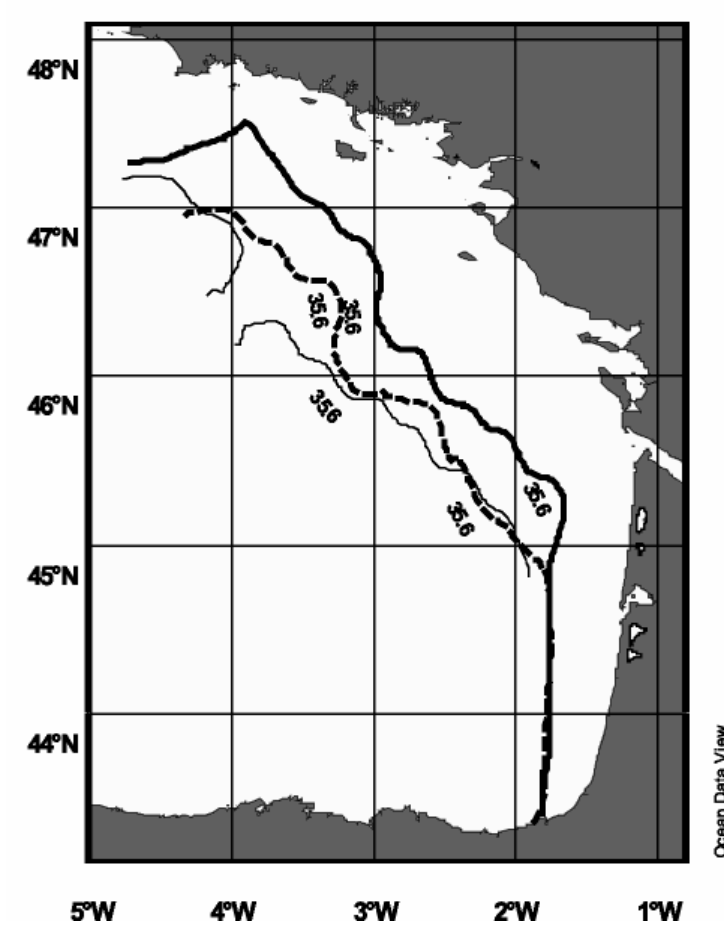

$S=35.6$ in June 1999

$\mathrm{S}=35.6$ in April 1998

- - - S=35.6 in April 1999

c/ Bottom salinity

Figure 5 


\section{MODYCOT 97-1: June 1997}

Surface Temperature $\left[{ }^{\circ} \mathrm{C}\right]$
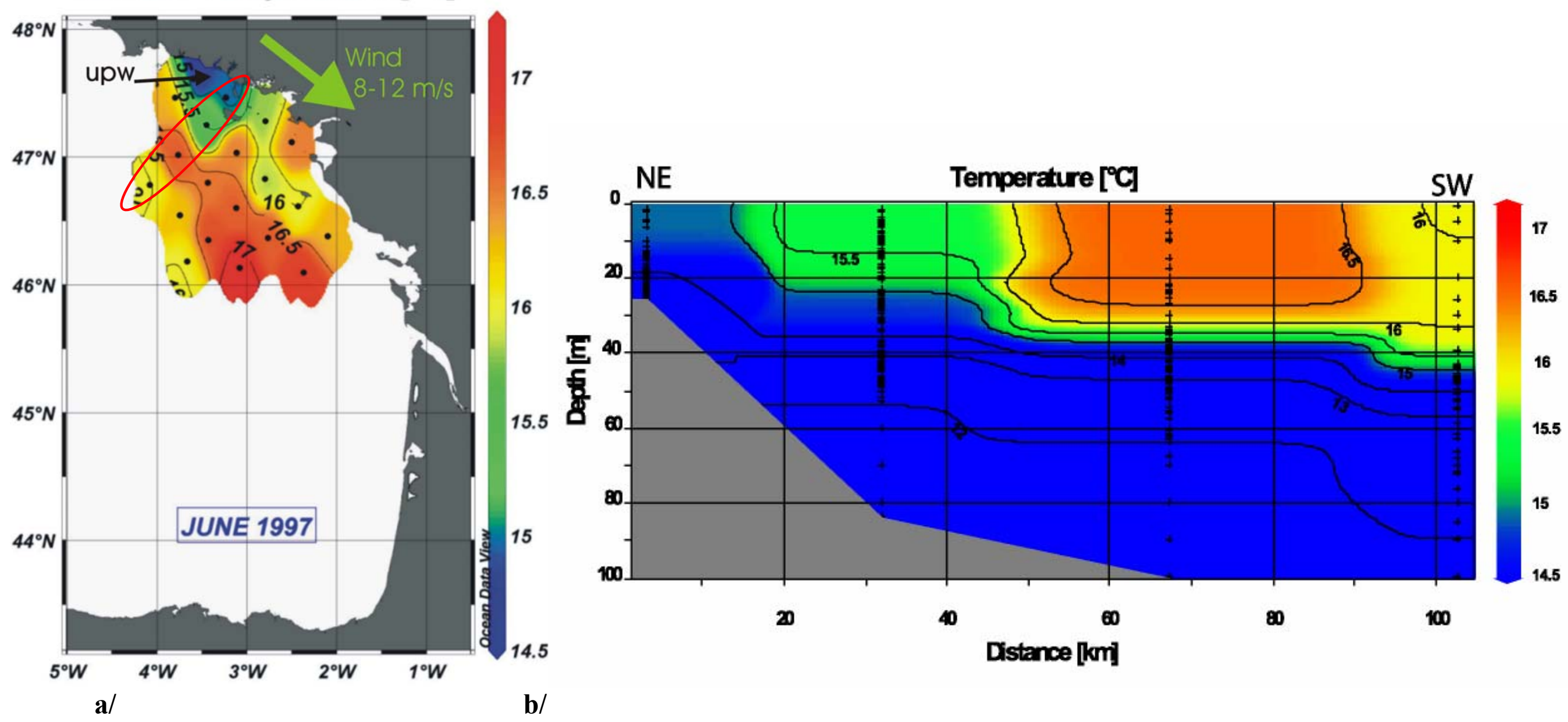

Figure 6 


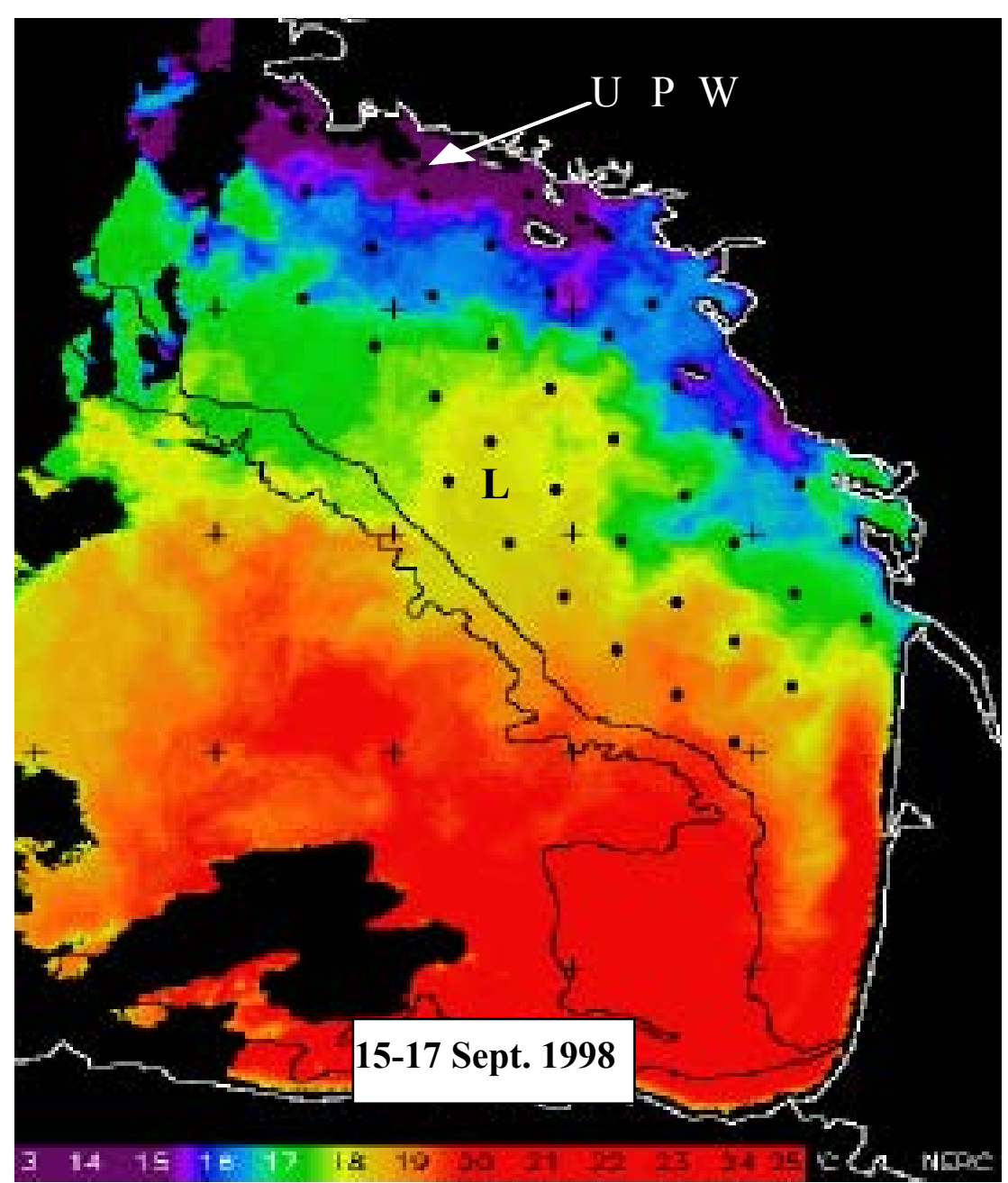

Figure 7 
MODYCOT 98-4: September 1998
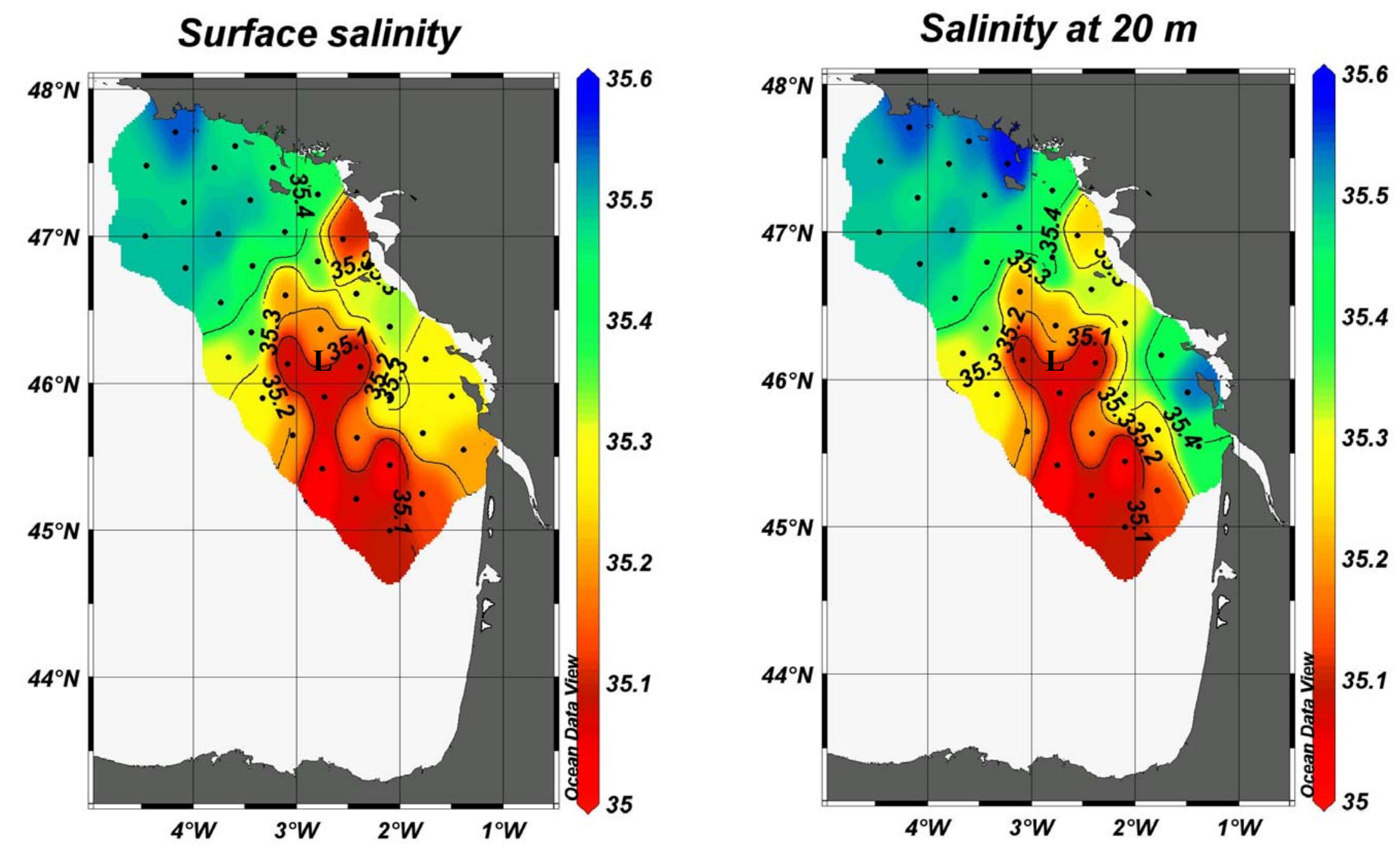

a/

Figure 8 
MODYCOT 98-4: September 1998
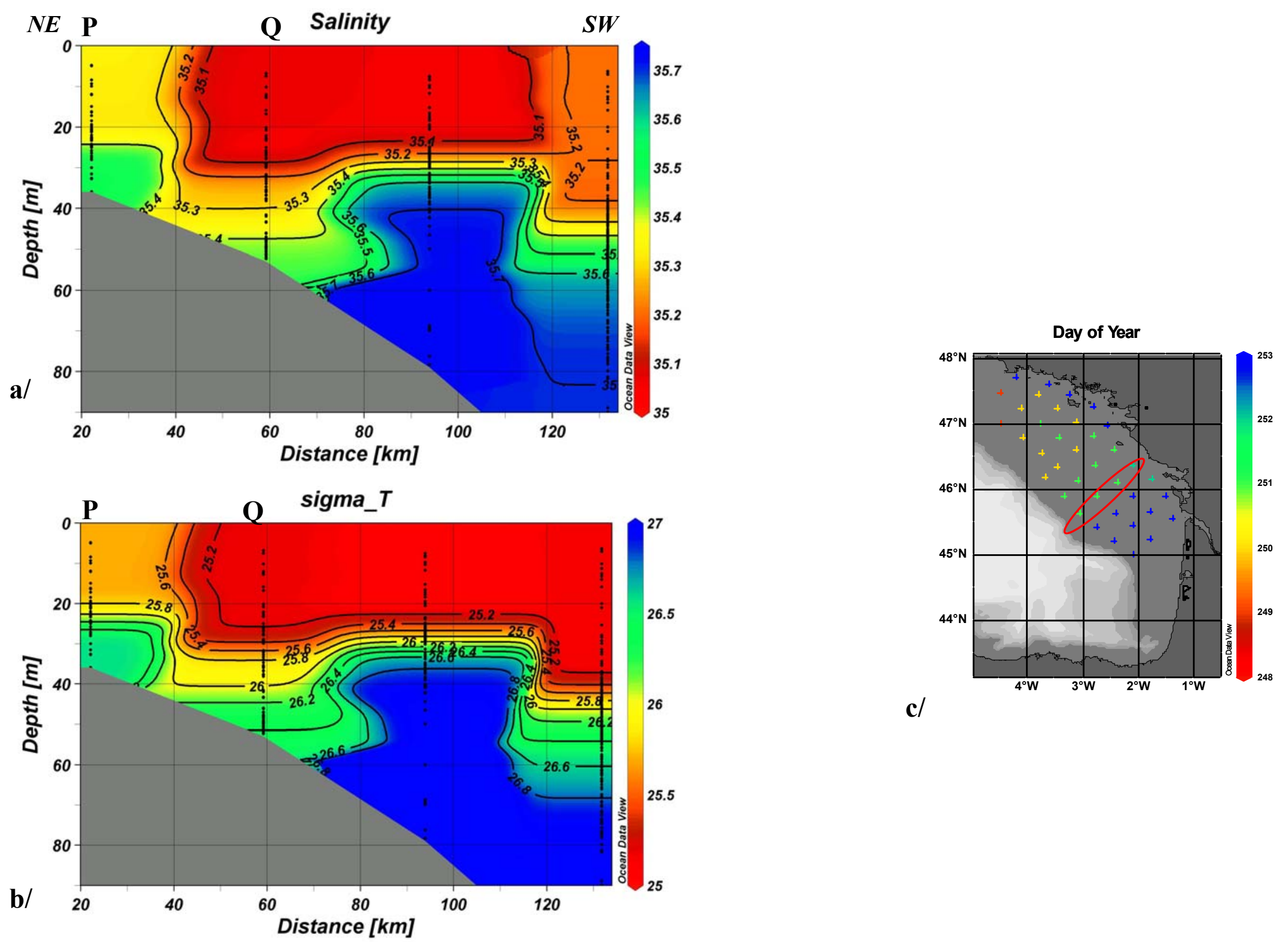

Figure 9 
MODYCOT 98-4: September 1998

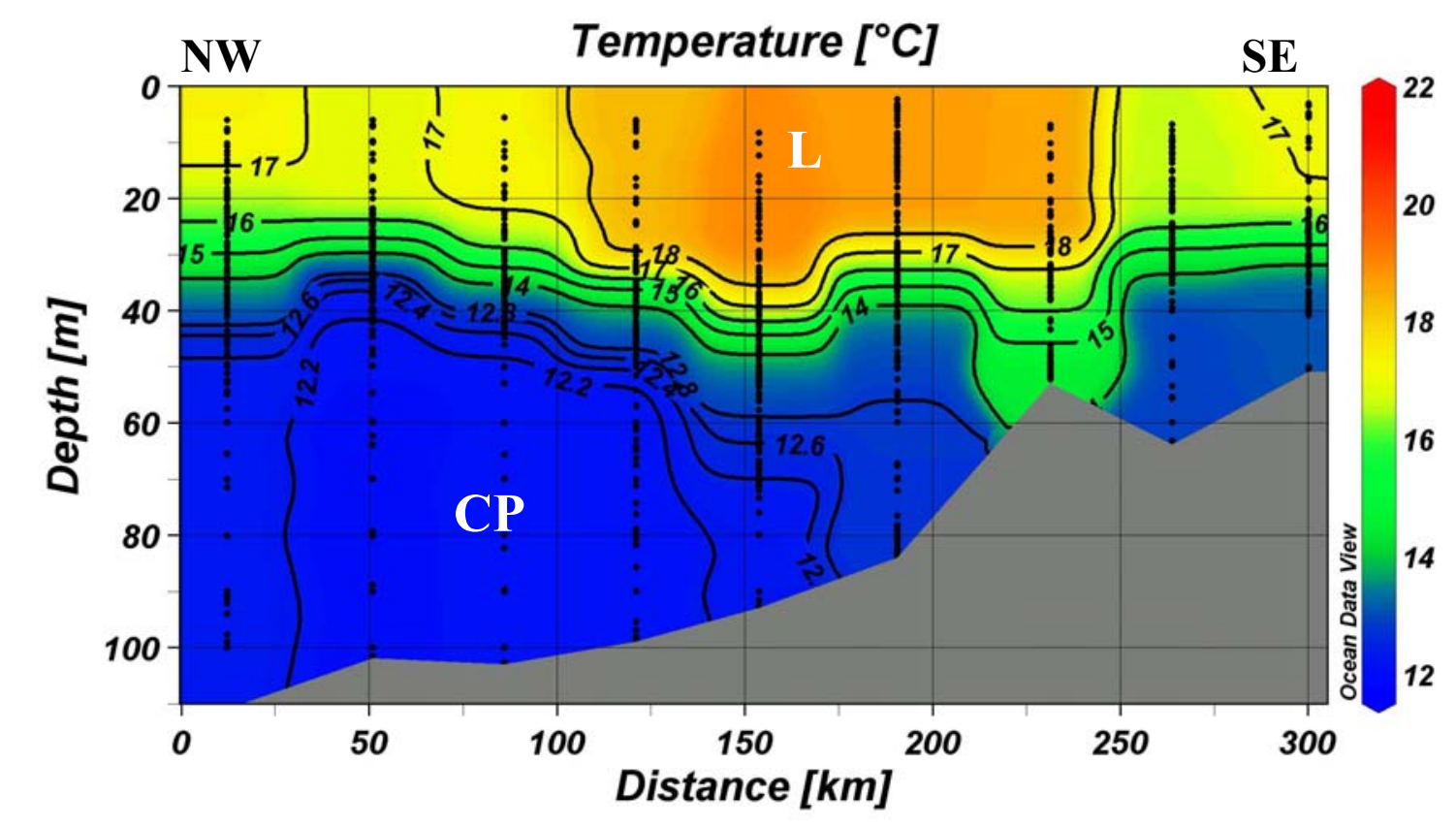

a/

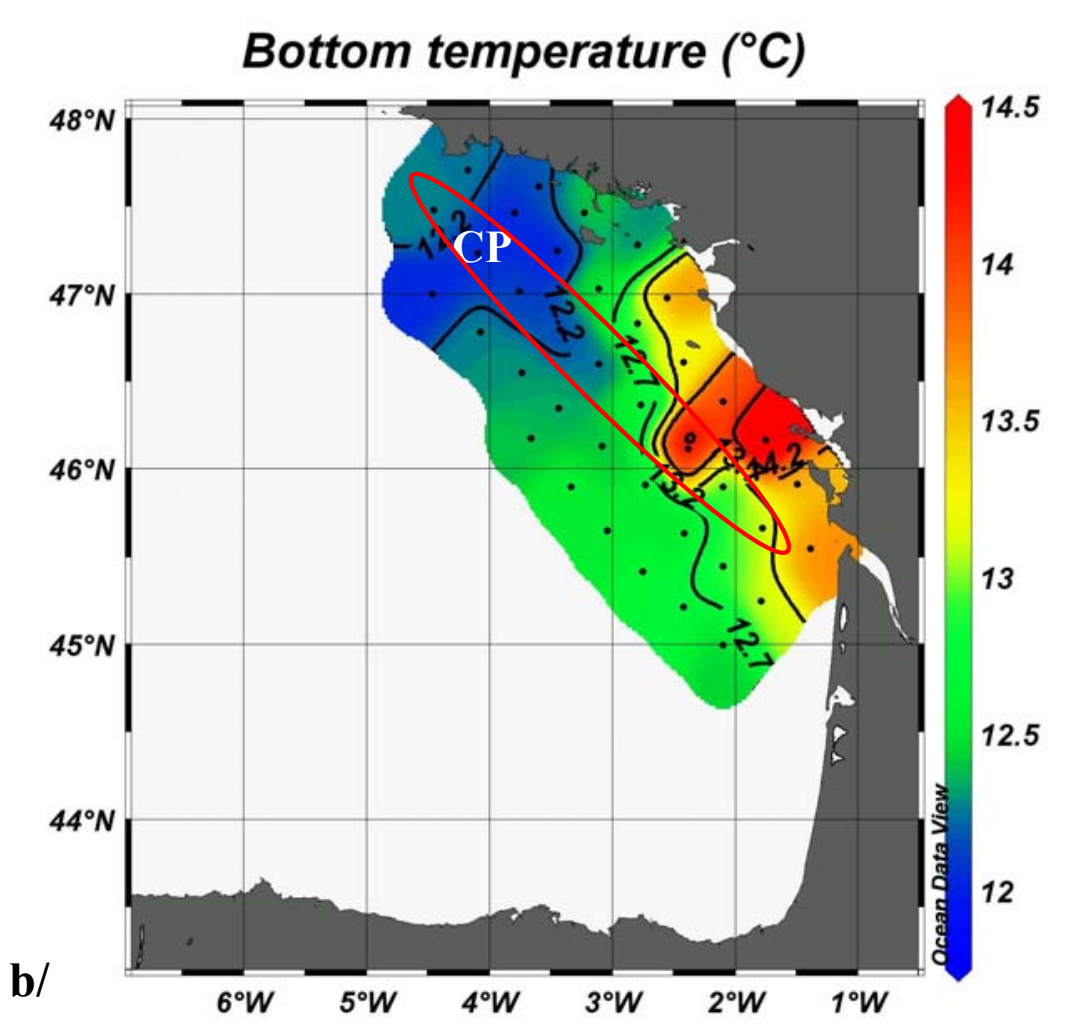

Figure 10 
MODYCOT 99-3: September 1999

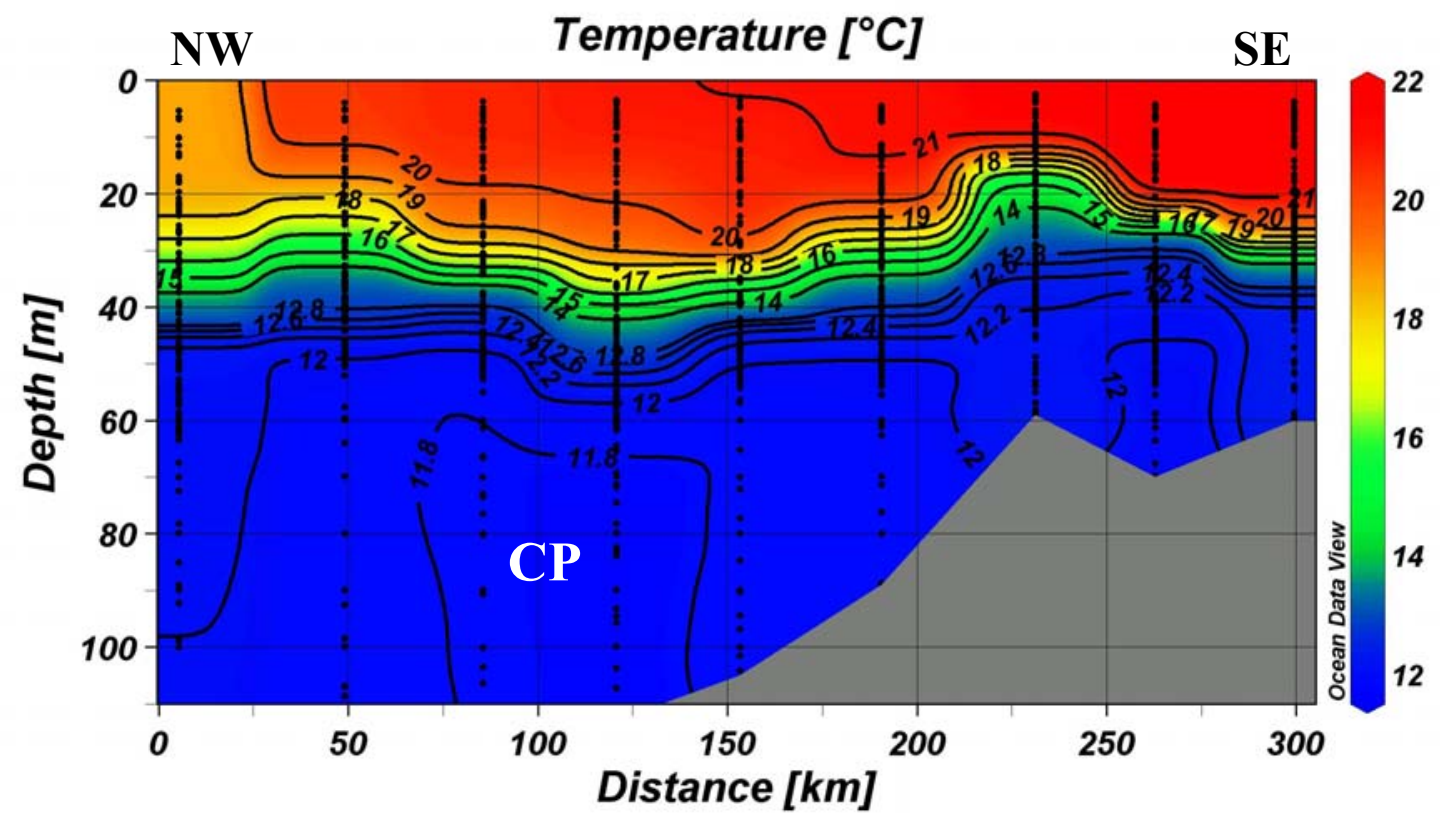

a/

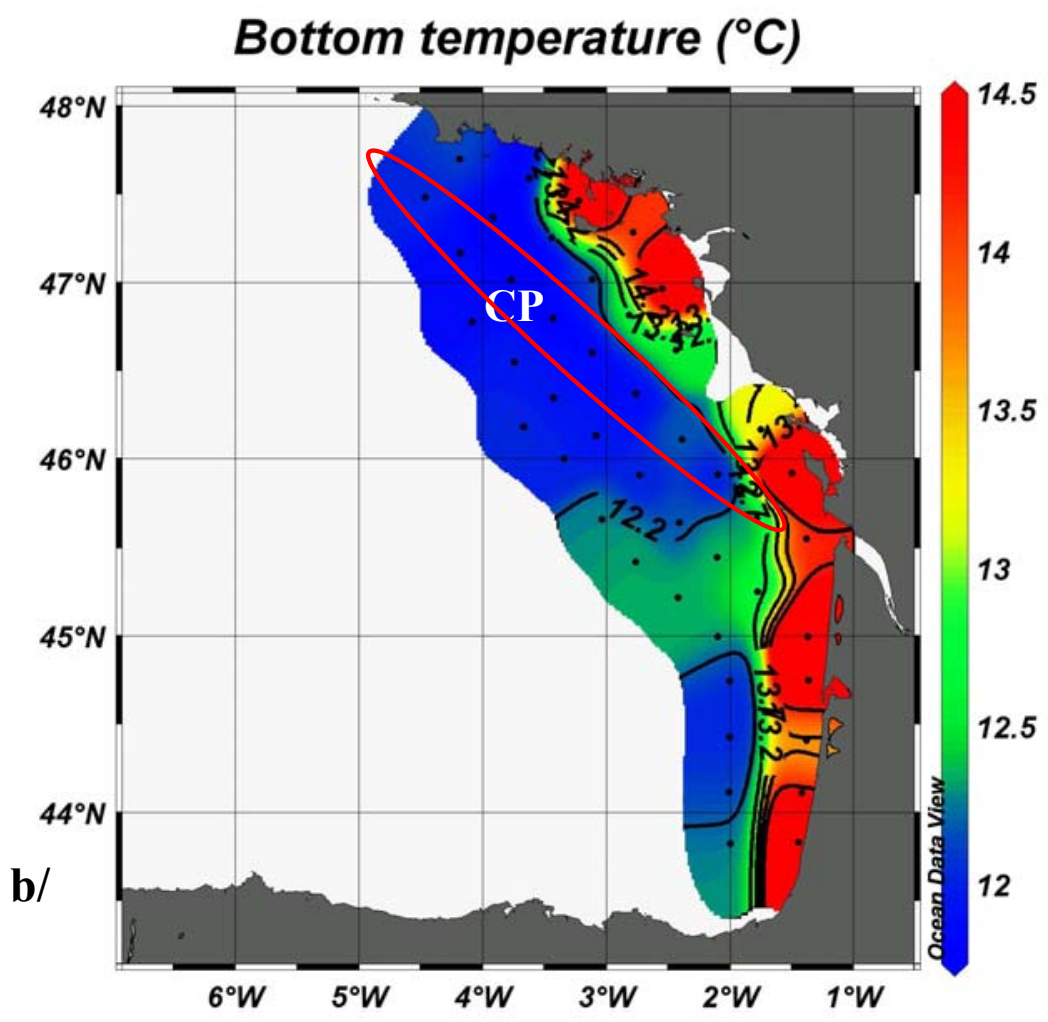

Figure 11 